\title{
European Competition Policy in International Markets
}

\author{
Olivier Bertrand \\ University of Toulouse (GREMAQ) \\ Marc Ivaldi \\ Toulouse School of Economics and CEPR
}

November 2006

\section{A contribution for the BRUEGEL's project on \\ EUROPE AND THE GLOBAL ECONOMY}

\section{Acknowledgement}

We are very grateful to Laetitia Driguez, Sean Ennis, Frédéric Jenny, Georges Molins-Ysal, Gunnar Niels, Valérie Rabassa and André Sapir for their insightful comments and suggestions. 


\section{Abstract}

Changes in the institutional, technological and economic environment raise new challenges to the European competition policy. First, firms' behaviour, particularly through international M\&A and hardcore cartels, could undermine benefits from globalisation. Together with the evolution towards more economic liberalization, markets have been reshaped by important technological improvements, putting forward new issues in terms of anti-trust policy, as shown recently by the Microsoft case. Lastly, these changes have been progressively accompanied by a newly institutional competition framework. The dramatic increase in the number of competition authorities incurs a waste of resources for multinational firms and anti-trust authorities and the risk of conflicting decisions between competition authorities. In parallel to these modifications, the EU has launched a vast program of reforms to modernize the European anti-trust policy. Both the institutional framework and substantive laws are being under reconstruction. It has notably driven to an on-going decentralization process of anti-trust laws enforcement and the creation of the ECN.

In this context, it is timely for European authorities to appraise the external dimension of the European competition policy as well as its articulation with current internal reforms. Globalisation can increase the costs of monitoring and seriously reduce the ability of European authorities to tackle crossborder anti-competitive conducts. In addition, conflicts are exacerbated by industrial policy motivations sometimes called economic patriotism - and 'beggar-thy-neighbour' policy.

As it is unlikely that the sole application of the territoriality and extraterritoriality principles to competition rules could yield an optimal international competition system, globalisation calls for higher levels and types of cooperation. Given that bilateral cooperation and especially the implementation of comity principles could be of no value when laws or interests are sources of international conflicts, three main paths could be therefore encouraged: The continuous harmonization of rules through the joint action of OECD and ICN, especially in the context of new-technology-based industries, which are a source of divergence among anti-trust authorities; the higher cooperation in the confidential information exchange; the establishment of global anti-trust institutions.

However, if WTO could serve as an institution to regulate global markets, especially due to its reliable dispute settlement body, it could certainly be relevant to distinguish trade and non-trade related competition affairs. Although WTO is legitimate in judging questions related market access and entry barriers, it is less equipped to assess international hard core cartels or M\&A reviews. As a substitute for WTO, a multilevel system, like the EU system, could be promoted. For political and pragmatic reasons, it could be composed in a first step of a hard core of countries like the EU, Japan and the U.S. It could be associated with the creation of an international Court of Justice for competition. In addition to these external reforms, some internal reforms could be required. Competition authorities have to develop further competition advocacy to give a higher priority to competition issues in other EU policies and national regulation. A parallel and complementary reform could consist in making the European competition agency independent from State Members' interference. 


\section{INTRODUCTION}

Competition policy and its enforcement face new challenges with the worldwide development of trade and investment liberalisation, as well as the widespread changes in technologies and institutions. A threefold objective is pursued here. This paper describes this new context; then it explains how the European competition policy accounts for this evolving situation; finally it proposes a set of directions which should or could be undertaken in the future.

With the advent of globalisation, market structures and economic environment have been deeply transformed. Improvements in transportation and communication, together with the increasingly removal of tariff barriers, has lowered transaction costs. It has stimulated trade flows, which has tended to decrease domestic prices and widen the range of goods available to consumers and industries. Coupled with a less strict foreign investment regime, trade liberalization has also encouraged foreign direct investments (FDI) and the expansion of multinational firms (MNE). Trade and FDI could be associated with pro-competitive effects on host countries. However, these gains have appeared quite fragile and reversible. In the eighties, benefits from trade liberalization eroded with the appearance of less transparent non-tariff barriers and contingent protection. One decade later, the concern that, without the intervention of competition authorities, the firms' behaviour could in addition undermine market integration and international competition, is more pronounced. State barriers could be substituted by private barriers, especially through vertical contracts, as in the famous alleged Kodak/Fuji case in $1996 .{ }^{1}$ (See Kojima, 2002.) In addition to vertical arrangements, companies could be tempted to recover profits and to restore their market power weakened by economic openness via cross-border M\&A or international hard-core cartels.

Cross-border M\&A have played an increasingly recognized role in the growing globalization of production since the beginning of the nineties. They progressively replaced greenfield investments as a mode to enter foreign markets over the nineties. ${ }^{2}$ FDIs have been submitted to a strong modification in composition. ${ }^{3}$ During this period, about 80 percent of FDI transaction value took the form of M\&A. (See

\footnotetext{
${ }^{1}$ In the Kodak/Fuji case, U.S. authorities accused the Japan of not sanctioning vertical restraints. The Fuji's control of the local film distribution system would have restrained the access of the U.S. firm Kodak to the Japanese photographic film market.

${ }^{2}$ A greenfield investment can be defined as the establishment of a new production facility in contrast to cross-border M\&A where a firm purchases shares of an existing foreign firm. Herein we indistinctly use the terms merger and acquisition.

${ }^{3}$ The surge in cross-border operations has been parallel with the outsourcing strategy and the fragmentation of the production process across countries. (See Evenett et al., 2000g.) With trade and FDI liberalization, the number of available input buyers increases, which diminishes hold-up behaviours. Vertical disintegration has some implication for antitrust authorities, since inter-firm transactions are indeed more exposed to antitrust scrutiny than intra-firm transactions.
} 
UNCTAD, 2000.) The nineties indeed experienced a spectacular surge in M\&A activity. ${ }^{4}$ (See, e.g., Bertrand et al., 2006; Evenett, 2003g, and Hijzen et al., 2005.) This phase was mainly characterized by the dramatic growth of cross-border operations. In 1999, the value of completed cross-border M\&A was around $\$ 720$ billion. (See UNCTAD, 2000.) In the nineties, cross-border M\&A represented more than one quarter of the total M\&A transactions in deal value. This wave of cross-border M\&A seems to have been induced by economic openness, although there is a lack of clear-cut empirical and theoretical evidence as research on international M\&A is still in its infant stage. ${ }^{5}$ (See Bertrand and Zitouna, 2006b.) Two strands of empirical study are noticeable. First, the welfare impact of cross-border M\&A is considered as ambiguous. (See, e.g., Horn and Persson, 2001; Norback and Persson, 2004 and 2005.) However, there are reasons to expect positive welfare gains. Indeed efficiencies gain could be more important for cross-border M\&A due to a higher complementary between merging partners, creating for instance a larger diffusion of know-how within the firm. In addition, reduction in competition could be less prevalent due to a lower overlapping of markets. Second, recent empirical studies seem to confirm rather positive effects of M\&A on productivity or R\&D activity. (See, e.g., Arnold and Smarzynska, 2005; Bertrand and Zitouna, 2006a, Bertrand and Zuniga, 2006.) However, M\&A continues to raise many concerns, especially in the public debate, as shown by the strong reaction of French politicians as a reply to the rumour of a take-over of the French company Danone by Pepsi Co or by the one of US politicians after the attempt of the Chinese company CNOCC to acquire the American petroleum firm Unocal. It is highly accentuated by the ineffectiveness of domestic competition policies when these operations could entirely or partially fall outside the control of national jurisdictions. The years 2001-2002 marked the end of the fifth wave in contemporary capitalism. The very recent years seem to indicate a recovery in M\&A activities, and notably in cross-border restructuring. (See European Commission, 2006.)

Besides M\&A, international hard-core cartels also jeopardize benefits from globalisation. ${ }^{6}$ The presence of international cartels for many years has been highlighted with the condemnation of the Lysine, Citric Acid and Vitamins cartels. Connor (2004) registers around the world more than 160 international cartels discovered from 1990 to 2003. All together they were fined for an amount of 10 billion dollar U.S.. Modern international cartels have distinct features. (See Connor, 2004; Evenett et al., 2001h, Levenstein et al., 2004.) Their members mainly come from the developed world, i.e., the U.S. and the EU, but also sometimes from Asian countries, particularly Japan and South Korea. They involve large multinational

\footnotetext{
${ }^{4}$ While the 20th century witnessed several waves of M\&A activity, the latest merger wave is unprecedented in terms of its size, sectoral coverage, and the number of nations whose firms participated in this wave. (See Evenett, 2003g.) M\&A activity peaked in 1999 when its total value amounted to an equivalent of 8 percent of world GDP. In comparison, this percentage is 0.3 in 1980 and 2.0 in 1990 respectively, these two years being the peaks of the last two waves of M\&A. (See UNCTAD, 2000.)

${ }^{5}$ It is beyond the object of this chapter to examine international M\&A. For empirical papers, see for instance Bertrand et al. (2006), Hijzen et al. (2005), Di Giovanni (2005), Gugler et al. (2003) or Raff et al. (2006). Theoretical aspects have been addressed for example by Bertrand (2005), Bjorvatn (2004), Kabiraj and Chaudhuri (1999), Lommerud et al. (2005), Qiou and Zhou (2006) or Neary (2004).

${ }^{6}$ International M\&A and cartels could be related. M\&A by reducing the number of competing rivals could facilitate the formation of cartels. It is also frequently emphasized that sanctioning cartels heavily could encourage firms to merge (or form joint-venture) in order to restore market power. (See Evenett et al., 2001h.)
} 
firms, selling worldwide elaborated products and service. These companies are fully aware of antitrust rules. Multinational firms are more frequently in contact, in time and places. The risk of collusion could be higher. ${ }^{7}$ They could also be more easily suspected ex-ante of anti-competitive behaviour such as blocking entry or using predatory pricing. Indeed, multinational firms could be endowed with a higher market power. MNEs are evolving in concentrated markets with high entry barriers. (See UNCTAD, 1997.) They usually do huge investments in $R \& D$ or marketing. These intangible assets confer large scale economies. They sell complex and differentiated products too. They have more deep pockets and external financing constraints. They could also manipulate transfer prices to their benefit.

Nevertheless, because of their clandestine and hidden nature, it is particularly difficult to know if this recent observed trend is a statistical fact only due to an improvement in the methods and means of detection of competition authorities and if not, to understand why international cartels are more and more frequent. As for international M\&A, economic literature on international cartel is lacking. However, this phenomenon is again certainly related to globalisation. For instance, globalisation improves communication and then fosters coordination and more collusive market outcomes. There is this conjecture that, with economic integration, some markets could become more concentrated which could facilitate collusion too. ${ }^{8}$ Most notably, damages to competition, efficiency and welfare could be substantial, especially for developing countries endowed with weak anti-cartel regimes. For all there reasons it is not surprising that, since several years, international cartel prosecution is a high priority on the agenda of the UE and U.S. authorities. Without information sharing and coordination between antitrust authorities, the ability of authorities to prosecute international cartels can be seriously reduced. As there are important difficulties to collect necessary evidence and to interview witness abroad as explained by Schoneveld (2003), cooperation among competition authorities become crucial.

Together with the evolution towards more economic liberalization, markets have been reshaped by important technological improvements over the last twenty years. These technological changes have been partly related to trade openness. Larger product markets stimulate innovation involving high fixed costs of research and infrastructure as they offer larger expected returns. One of the main features of recent technological progress has been the development of network-based industries. (See Röller and Wey, 2002; and Evenett et al., 2000g.) These industries are characterized by a high level of concentration. The leverage of market power from one product to another could drive to a global dominance and its abuse, as some parties have argued in the Microsoft case. Network externalities tend to favour industrial concentration too: the value of a product for consumers depends on the number of other consumers. Firms are then encouraged to gain first-mover advantages by lowering prices and expanding sales, reinforcing

\footnotetext{
${ }^{7}$ See the literature on multi-market contacts, for instance Scott (1989 and 1991) and Bernheim and Whinston (1990).

${ }^{8}$ In the opposite, a higher transparency enables buyers to search for the best product, which can undermine collusive discipline. However, more blurred frontiers make the natural geographic division of markets less obvious.
} 
the demand for the firm. Consumers can benefit to national and international externalities and complementarities, but also be hurt by associated switching costs and lock-in effects. As network effects can favor concentration and/or cooperation among firms, e.g., on standard setting, product compatibility, or licensing, regulators need to rethink the economic framework and to adapt the tools of competition policy. It will constitute a new source of anti-trust debate and thereby likely disagreements among academics and competition authorities as shown again very recently by the case of Microsoft. ${ }^{9}$

The economic and technological changes have indeed been progressively accompanied by a newly institutional competition framework. For some years, there has been a dramatic increase in the number of competition authorities. In 1989, only eleven developing countries and twenty OECD members were endowed with competition laws. (See Schoneveld, 2003.) In 2003, more than one hundred countries have adopted competition rules. As a consequence, the overlapping of domestic regimes has entailed duplicated costs due the process of legal affairs and a waste of financial and human resources for multinational firms. It also represents additional costs for anti-trust monitoring caused by multiple reviews, redundant filing and reporting. Besides, it is a source of political and business uncertainty. Authorities' decision can be contradictory, leading to conflict and even the risk of trade war as in the McDonnell-Douglas-Boeing case. ${ }^{10}$ All these inconvenience are amplified when anti-trust rules are different from one country to another or/and when the expected impact of alleged anti-competitive behaviours are unequal across countries.

The modification of institutional, economic and technological environment poses new challenges to the current European competition policy, which has been under a continuous reconstruction since several years. It is important to recall that the early beginning of the anti-trust European regulation dates from the treaty of Paris in 1951 and the creation of the European Coal and Steel Community. European competition laws were really founded with the treaty of Rome in 1957. Competition policy basically aims at promoting and safeguarding competition and market functioning to the benefit of the economy. Anti-trust rules are articulated around Article 81 to Article $89 .{ }^{11}$ The cornerstone of the European competition policy is constituted of Article 81 on horizontal and vertical restrictive agreements and Article 82 on the abuse of dominant positions. ${ }^{12}$ Merger regulation was born later in $1989 .{ }^{13}$ The EU commission sets up a unique stop-shop regulation and introduces guidelines with the objectives to reduce business uncertainty. Both

\footnotetext{
${ }^{9}$ See The Economist, Microsoft on Trial, April 28th, 2006.

${ }^{10}$ Conflicts are of course not confined to the U.S.-EU relation. South Africa complained in 1996 for the prohibition of the merger between Lonrho and Gencor. U.S. authorities also blocked mergers between European companies approved by the European commission, e.g., BOC-Air Liquide merger in 2000.

${ }^{11}$ Note that the Article 87 and 88 refer to states aid. The DG Competition controls that State aids do not distort intra-European competition. A complete analysis of the impact of state aids and its enforcement by the DG Competition and other European bodies is beyond the scope of this text.

12 The articles 85 and 86 of the treaty of Rome (1957) were replaced by the articles 81 and 82 of the treaty of Amsterdam (1997).

${ }^{13}$ Before 1989, merger regulation was based indirectly on articles 81 and 82 . The first prohibition of a merger took place in 1971 with the Continental Can acquisition.
} 
reforms were supported by the business community. (See OECD, 2005.) The increasing number of large European cross-border mergers called for a more transparent and quick scrutiny to reduce business uncertainty. The Single Market program also required a stricter enforcement of competition rules. Again, since several years, the EU has again launched a vast program to modernize the European anti-trust regime. Both the institutional framework and substantive laws are being reformed. First, there has been an on-going process of decentralization with the joint responsibility of the Commission and national authorities to enforce anti-trust laws. It was accompanied with the creation of the European Competition Network (ECN) since May 2004 and the application of the new 2003 regulation. ${ }^{14,15}$ Second, the notification system for agreements has been abolished. The legal exemption regime shifts from an ex-ante to an ex-post monitoring system. It permits the reallocation of the European resources to the prosecution of hard-core practices. The Commission has been endowed with new powers in terms of investigation, sanction and decision. Finally, substantive laws are going from a legalistic to a more sound economic approach, affecting all anti-trust fields. This policy of reform is driven by the momentum in the liberalization process of sectors like gas, electricity or telecommunication, and the enlargement to Central and Eastern Europe countries (CEECs). It implies the rationalisation and reorganisation of the anti-trust regulation framework. Furthermore, the modernization of the Merger policy through the new Merger 2004 regulation was inevitable since several decisions of the Commission have been rejected by European courts in 2002 (as in the case of Airtours-First Choice, Tetra laval-Sidel or Schneider-Legrand). ${ }^{16}$ It led to the dissolution of the Merger Task Force after 2003 and the hiring of a chief competition economist. More generally, the evolution of anti-trust laws stems from an increasing awareness of the importance of a sound economic analysis in policy decision-making. This awareness of the EU has certainly been stimulated by discussions and works performed in different institutional areas, like the International Competition Network (ICN) or the OECD. European competition reforms are also to be placed within the context the Lisbon's agenda. For a long time, the main objective of the European competition policy was the construction of a European integrated market. With the progressive achievement of the internal market, the objective of market integration has become less a priority. It was progressively replaced by economic efficiency purposes. This new objective was enhanced in 2000 with the Lisbon's agenda. The goal is to make the EU by 2010 "the most competitive and dynamic knowledge-based economy in the world capable of sustaining economic growth with more and better jobs and greater social cohesion”. ${ }^{17}$ As

\footnotetext{
${ }^{14}$ See Council Regulation (EC) No 1/2003 of 16 December 2002 (OJ 2003, L1).

${ }^{15}$ The ECN constitutes a network of EU competition authorities exchanging information, allocating cases and undertaking joint investigations. It should guarantee the homogeneity of the application of EU rules.

${ }^{16}$ See Council Regulation (EC) No 139/2004 of 20 January 2004 (OJ 2004, L24).

${ }^{17}$ In this chapter, we do not provide a full account of the interaction between competition policy and the intellectual property regime. (See Crampes et al., 2005.) The EU grants no intellectual property rights, expect trademarks. These rights are enforced at the member states level. It is complemented by the European patent convention signed in 1973. The European patent office permits one-stop shop review by proposing a bundle of national patents.
} 
clearly underlined by the Commission's 2004 annual report on competition policy, European authorities have to enforce and foster competition to improve economic efficiency, increase productivity growth and promote the competitiveness of the European Community on global markets. (See Monti, 2003, 2004a, 2004b.)

In this context of on-going reforms due to multiple but convergent factors, the international dimension of the European competition policy is becoming more prominent, raising new issues. It is necessary to fully understand them and to integrate and articulate both the external and internal dimension of European reforms. As you will extensively explain, globalisation can increase the costs of monitoring and seriously reduce the ability of European authorities to tackle cross-border anti-competitive conducts. In addition, conflicts are exacerbated by industrial policy motivations - sometimes called economic patriotism - and 'beggar-thy-neighbour' policy. Since the territoriality and the extraterritoriality application of competition rules only are unlikely drive to an optimal international competition system, globalisation calls for a higher cooperation. This cooperation could go through the adoption of a package of hard and soft laws, at a bilateral, plurilateral - notably via the inclusion of anti-trust provisions into regional trade agreements - and multilateral level - through different institutions like the ICN, the WTO or the OECD. It requires a higher neutrality and credibility of actions, as well as the influence of European competition authorities within Europe.

The objective of this paper is therefore to contribute to the current debate as follows: Section 2 describes the institutional aspects and the different instruments of the external dimension of the European competition policy. Section 3 recalls the theoretical and empirical arguments presented in the economic literature that are the basis for designing competition policy in international markets. From these different elements, the last section provides some recommendations for the European competition policy now and tomorrow.

\section{THE EXTERNAL DIMENSION OF THE EUROPEAN COMPETITION POLICY}

While Articles 81 and 82 of the Rome treaty are the cornerstone of the European competition legislation, they do not mention the scope of the European jurisdiction explicitly as noticed by Kojima (2002). They state that alleged practises "may affect trade between member States" or may have "an anti-competitive effect in the Common market". The impact of trade can be "direct or indirect, actual or potential." (See Sugden, 2002; Hamner, 2002.) 
European rules apply to practices impacting inter-state trade. (See Grisay, 2005.) Abuses of dominant position and prohibited arrangements are subject to the EU law if they affect intra-European trade, irrespective of whether it originates from the EU or from non-EU countries, i.e., of the nationality of parties. It is usually the situation of a company whose activity covers several Member states. It is also required that the anti-competitive impact takes place within the Single market. It guarantees free competition within the EU.

This first section depicts the institutional and political framework of external features of the European competition policy, that says the application and interpretation of the extraterritoriality principle over time in Europe, the bilateral and plurilateral agreements established with main trading partners (mainly through regional trade agreements), and the multilateral negotiation formed by the WTO, OECD, ICN or UNCTAD.

\subsection{The extraterritoriality principle}

Articles 81 and 82 are consistent with the objective of an European integrated market as they define the geographic application of the EU law and specify competencies of the European commission and the member states. Nevertheless, it neglects potential behaviours from companies outside the EU. Thus, the EU was obliged to use two other principles to solve this question of competence: the so-called economic unit and extraterritoriality principles. (See Grisay, 2005.)

In the Dyestuff case in 1972 or in the Continental can case one year later, both the Court and the Commission refers to the unity of a group of firms. ${ }^{18}$ (See Davison and Johnson, 2002.) This principle assigns the practices of affiliates established within the EU to its parent company located abroad. The parent company has indeed a decisive influence on its subsidiary. The foreign parent is therefore viewed as acting within the Community. Increases in prices could be decided outside the Community and implemented by affiliates within the European market. This principle is consistent with the territoriality principle.

The extraterritoriality principle is applied when companies involved do not have affiliates within the EU market. (See Falvey and Lloyd, 1999.) It consists in the prosecution of firms whose anti-competitive behaviours affect a territory, irrespective of their country origin. National laws are applied to companies located within the territory of another nation. In 1977, the Commission stated for instance that they "can act against restrictions of competition whose effects are felt within the territory under their jurisdiction, ${ }^{18}$ Imperial chemical Industries Limited v European Commission, case 48/69, 1972, p 619. Continental Can, case 6/72, 21 February 1973, ECR
1973. See Grisay, 2005. 
even if companies involved are locating and doing business outside the territory, and of foreign nationality, have no link with that territory, and are acting under an agreement governed by foreign law.” (See Kojima, 2002.)

In the Wood Pulp case in 1988, the European Court of Justice (ECJ) confirms the use of the extraterritoriality principle by the Commission. ${ }^{19}$ In 1984, companies from U.S., Canada, Norway, Portugal and Spain were accused by the Commission of collusion on prices in the European Wood Pulp market, breaching Article 81. Defendants claimed that the EU lacks jurisdiction over them since they are not established within the EU. Many of the defendants had no affiliate within the EU. They also explained that one of the U.S. defendants was involved in an export cartel, which were legally authorized in U.S. Action from the EU would have therefore violated the public international law duty of non-interference. The European Court of Justice rejected both these claims. First, asserting jurisdiction was justified on the ground that "the producers implemented their pricing agreement within the common market". "It is immaterial whether or not they had recourse to subsidiaries, agents, sub-agents, or branches within the Community in order to make their contacts with purchasers within the Community.” (See Sugden, 2002.) The explanation of the jurisdiction was based on the effects of their actions, and not on their location or nationality. This has been called the Implementation doctrine. ${ }^{20}{ }^{21}$ What matters is not the place where the agreement or the decision is taken but where it is implemented, i.e., where products are sold. Here, the pricing agreement was implemented within the European Union. (See Kojima, 2002, and Fiebig, 2005.) Jurisdiction is grounded on the territoriality principle and thus recognized by public international laws. Second, the alleged breach of the public international law on the duty of non-interference was also rejected. It only occurs when the duties in one country are prohibited by the laws of another country. The ECJ finds no conflict since US laws were not infringed: U.S. laws regulating export cartel do not include any requirement that firms should be exempt from EU competition laws. (See Sugden, 2002, and Hamner, 2002.)

\footnotetext{
${ }^{19}$ A Ahlström Osakeytiö and others v Commission, case 89,104, 114, 116, 117, 125, ECR 1988 p 5193. See Grisay, 2005.

${ }^{20}$ The Implementation doctrine is called the Effect doctrine in the U.S. In practice, these two concepts are rather similar even if there is no clear consensus. According to Kojima (2002), the Commission adopted the Effect doctrine, while the ECJ used an objective territorial principle. Differences between the Effect doctrine and the Implementation doctrines may exist when an agreement implemented outside the EU produced some effects on the EU market. (See Davison and Johnson, 2002.)

${ }^{21}$ The U.S. Supreme Court examined the extraterritorial principle the first time in 1909 for the American Banana Co. v. United Fruit Co. This principle was denied since actions did not occur within the U.S. A US-based trader in Costa Rica accused another US-based trader in Costa Rica on anti-competitive practices on the Costa Rican Banana trading market. (See Sugden, 2002 or Kojima, 2002.) The U.S. applied the extraterritorial principle the first time for the Alcoa case in 1944. It fines an agreement by companies outside the U.S. which has the effect to reduce exports to the U.S. (See Kojima, 2002.) The Foreign Trade Antitrust improvements Act in 1976 prosecuted foreign behaviours that have a direct, substantial and reasonably foreseeable effect on U.S. commerce. This is the theory of intended effect discussed by Kojima (2002). In the eighties, U.S. antitrust authorities used the consumer welfare approach in international issues. Jurisdiction can pursue foreign firms involved in imports conducts that hurt U.S. consumers. In the 1990s, the enforcement policy was officially extended to harmful practices to U.S. exports of goods and services, i.e., to U.S. companies. (See Falvey et Lloyd, 1999.) This extension first appeared in the 1980s in a context of trade deficit and tension, notably with Japan. This extension was criticized by the EU. It is important to emphasize that the EU has refused to extend the extraterritorial principle to the defence of EU exporters and to introduce motivations in terms of market access.
} 
There was another judicial step with the Gencor-Lonrho case in 1999. ${ }^{22}$ (See Davison and Johnson, 2002.) In this case, the concern involved a merger between two South African companies. The Court of First Instance examined the geographic scope of the Merger Regulation and referred to the Wood Pulp case to confirm that the action from the Commission was legal. ${ }^{23}$

This extraterritoriality principle, as all unilateral economic policy, presents some important drawbacks. Political limits are clear: Depending on the power of antitrust regulators, this principle can settle international anti-trust issues. However, it can also amplify conflicts and thereby generate serious tensions. For instance, the Boeing-Mc Donnell Douglas case was accompanied with rumours and speculation of conflict escalation and retaliation of the U.S. against the EU if the Boeing-Mc Donnell Douglas merger had been effectively sanctioned. ${ }^{24}$ (See Aktas et al., 2000.) There are also judicial limits: countries have adopted measures to prevent what is often considered as a violation of sovereignty. We return later on the political impact of the extraterritoriality principle later.

\subsection{Bilateral Agreements and Regional Trade Agreements}

The EU authorities have signed bilateral agreements to enhance the share of information, the coordination of procedures and the convergence on substantive issues. ${ }^{25}$ (See Röller and Wey, 2002.) There exist different levels of bilateral cooperation, going from notification to negative comity. (See Bode and Budzinski, 2005; Haucap et al., 2005.)

First, cooperation could imply notification. A country aware of some potential anti-competition practices notifies it to the affected competition authority. Second, there could be consultation: Authorities help each other on the substance of an investigation, notably through an exchange of information. Two other mechanisms of cooperation exist: the negative and positive comity. They are less frequently included in agreements and take the form of non-binding commitment. They aim at preventing the extraterritorial application of domestic laws. The negative comity states that an authority has to take into account the consequences of its actions on the other country. (See Bode and Budzinski, 2005.) Each authority respects the sovereignty and interests of other countries. The positive comity principle states that

\footnotetext{
${ }^{22}$ Gencor Ltd vs. Commission, (1999), case T-102/96, ECR, page II-0753.

${ }^{23}$ It was more complex to define the geographic scope of jurisdiction in this Gencor-Lonrho case because of the already existing test of the European Community dimension. A concentration has a community dimension only if the combined aggregate worldwide turnover of all the undertakings involved exceeds 5 billions Euros and the aggregate community-wide turnover of each of at least two of the undertakings involved exceeds 250 millions Euros, unless each of the undertakings has more than two-thirds of their community-wide turnover within the same European member state. This criterion applies to all firms irrespective of the place where they are registered and produce.

${ }^{24}$ Boeing accepted to give up its exclusive contracts with air flight companies. Note that the Commission could not have prohibited this operation, but only imposed heavy fine (up to $10 \%$ of the turn-over). Purchase of Boeing or Mc Donnell Douglas air flight by European companies could have been forbidden too.

${ }^{25}$ See the website of the Competition Directorate General for a complete list of bilateral and multilateral agreements.
} 
a domestic authority acts on the behalf of the foreign country against domestic firms adopting anticompetitive behaviours abroad. The domestic authority refers to its domestic laws to protect the interest of its partner country.

The EU has signed bilateral agreements with all its main trade partners. (See Grisay, 2005.) First, bilateral cooperation has been used to impose to European neighbour countries a similar model of competition regulation. A first example is the European Economic Area and the Porto agreement which was signed in 1992 between the EU and the EFTA (European Free Trade Association) States. It aims at ensuring identical conditions of competition and designing rules of competence. It is based on a one-stopshop principle where cases are allocated either to the EU or the EFTA authorities or on a deep cooperation in terms of exchange of information or administrative assistance. A second example is the free trade regional agreement with the Eastern European countries (CEECs) in which competition provisions were included. A major condition for their accession was the respect of European competition rules. Similarly, the Euro-Mediterranean free trade agreement contains competition provisions aiming at promoting convergence of laws and cooperation. Note that regional trade agreements (RTA), which are mainly signed between developed and less developed countries, have represented these last years the main channel of diffusion of anti-trust rules. Provisions are often expressed in terms of market access. They are declared to be implemented to avoid that trade agreements be undermined by anti-competitive practices. (See Evenett, 2005e.)

Second, cooperation with non-neighbour countries is aimed at contributing to a higher cooperation and to some degree to convergence. (See Davidson and Johnson, 2002.) The Commission has formal cooperation agreements with Canada, Japan and the U.S.. The Commission also keeps a relationship with Australia, China, Korea, or Mexico. (See OECD, 2005.) The most important and comprehensive bilateral agreement was signed with the U.S. anti-trust authorities. Because of its economic importance and scope, we describe it comprehensively.

Cooperation between the U.S. and the EU was established in 1991. It comes into force in 1995, once accepted by the Council of Ministers. In addition to notification of cases and exchange of information on general matters, the 1991 agreement is based on the traditional concept of (negative) comity while it also includes the instrument of the positive comity. (See Bevin and Echevarria, 2005.) Articles V and VI respectively refer to the positive and negative comity principle. ${ }^{26}$ (See Montini, 1999.) None of these two articles implies binding obligations. A second agreement is signed in 1998. It aims at giving more details on the place of positive comity. (See Davison and Johnson, 2002, and Bevin and Echevarria, 2005.) Indeed the prior agreement lacked a test determining when the positive comity principle can be

\footnotetext{
26 "If a party believes that anticompetitive activities carried out in the territory of the other Party are adversely affecting its important interests, the
} first Party may notify the other Party and may request that the other Party’s competition authorities initiate appropriate enforcement” 
implemented by authorities. For this reason Article III of the 1998 EU-U.S. Agreement adopts a new definition of the positive comity principle. ${ }^{27} \mathrm{~A}$ party can request the competition authorities of the other party (the requested party) to launch an investigation even if the presumed anti-competition behaviour does not violate the other party's competition laws or the competition authorities of the other party have no interest to take any enforcement activities, and the requested party has a general duty to act in conformity with the request. (See Montini, 1999.) Since it was amended in 1998, the positive comity principle has been seldom used, only one time in the Sabre/Amadeus case in $1998 .^{28}$

These arrangements have nevertheless facilitated co-ordination in merger and cartel cases - especially with simultaneous international cartel investigation and inspection as in 2003 in the plastic additives industry. (See Bevin and Echevarria, 2005.) Cooperation led to important convergence on leniency programmes too. The EU revised its leniency programme in 2002, making it more transparent and credible. ${ }^{29}$ It should be pointed out that the U.S.-EU agreement does not include merger regulation control. So, a specific protocol on merger reviews was adopted in 2002. It is aimed at facilitating cooperation through parallel timing of investigation and share of information.

However, cooperation agreement revealed insufficient because of a limited exchange of information constrained by confidentiality rules or of the persistence of inefficiency from multiple competence and jurisdiction. Besides, it does not seem to resist to serious political and economic turmoil.

\subsection{Multilateral framework}

A first attempt of multilateral cooperation goes back to the Havana Charter in 1946-1947. The Havana Charter was related to the International Trade Organization. It included an important chapter (Chapter V) on restrictive business practices which could be harmful to trade. Concerns were related to the behaviour of German cartels and Japanese zaibatsu in the pre-war period. However, the Havana Charter failed to be ratified as it was rejected by the U.S. congress, which certainly did not want to abandon some part of its sovereignty. Part of it was integrated in the General Agreement on Tariffs and Trade (GATT), signed in 1947 and applied from 1948, The GATT, a multilateral agreement designed to provide a framework of rules and a forum to negotiate trade barrier reductions among nations, contains no explicit provision on

\footnotetext{
${ }^{27}$ Article III states that "The competition authorities of a Requesting Party may request the competition authorities of a Requested Party to investigate and, if warranted, to remedy anticompetitive activities in accordance with the Requested party's competition laws. Such a request may be made regardless of whether the activities also violate the Requesting party's competition laws, and regardless of whether the competition authorities of the Requesting Party have commenced or contemplate taking enforcement activities under their own competition laws.”

${ }^{28}$ The U.S. Department of Justice formally requested the European Commission to investigate allegedly anticompetitive practices by European airlines against U.S. enterprises.

${ }^{29}$ Cooperation on merger reviews is more active than on cartels or other anti-competitive practices because of the firms' lobbying. Companies are supporting a higher coordination among authorities in M\&A transaction since they have to face several procedures from different regulators. Firms are more reluctant to such coordination for cartel prosecution.
} 
anti-trust issues. Their introduction was discussed before the Uruguay round in the nineties, but was finally removed from negotiation. However, there were some indirect references on competition issues, especially for public procurement, as noticed by Messerlin (1995).

The OECD and UNCTAD have been also used as a forum for encouraging multilateral cooperation since the seventies. The OECD adopted different recommendations over time on anti-competitive conduct affecting trade as well as directives on multinational firms' behaviour. (See Messerlin, 1995.) The OECD recommendation on anti-competitive practices affecting trade goes back to 1967. It was revised several times, like in 1973, 1979 or 1986. In 1995, the OECD underlined the need of cooperation among national authorities in the investigation and prosecution of anti-competitive practices via the exchange of information, automatic notification and a higher coordination of proceedings. It also fostered a voluntary conciliation procedure and the application of the positive comity principle to prevent and solve conflicts of competence. (See Grisay, 2005.) In 1998, for instance again, OECD issued a recommendation on effective actions against hard core cartels. Very recently in 2005, it adopted a new recommendation on best practices for merger review. There was also an active debate within the UNCTAD (United Nations) on multinational firms in developing countries and the control of restrictive business practices (particularly the condemnation of international cartels). It resulted in the adoption of a best endeavours set of principles in 1980. The effort of the UNCTAD revealed to be very useful, especially by providing technical assistance to developing countries.

Another instrument of multilateral regulation is the World Trade Organization (WTO). Following the different GATT rounds, the WTO is then set up in 1994. This institution is organizing international trade relations. The WTO is now an important player in multilateral trade policies. It aims at resolving trade conflicts and monitoring national trade policies. Member states are obliged to respect rules imposed by the WTO. There exists an effective dispute settlement system to ensure the legitimacy and enforcement of rules. Countries affected by claimed misbehaved practices can request to the WTO.

In the beginning of the 1990s, the EU launched the idea of including a competition policy regime into the WTO. It was first suggested by Leon Brittan in 1992 at the World Competition Forum at Davos, and then proposed in the Van Miert report in 1995. (See Kojima, 2002, and Evenett et al., 2000g.) The EU proposal contains several elements as explained by Grisay (2005): a binding cooperation (automatic procedure, exchange of non-confidential information, introduction of the negative and positive comity principle); the definition and adoption of minimal standard laws (core principle) related to restrictive business practices and the abuse of market power (parallel with the principle of national treatment and non discrimination and that of transparency); the implementation of a dispute settlement procedure, but only for breaches of common principles and its enforcement. Following the EU initiative, a working group within the WTO was constituted in 1996 at the Singapore Ministerial meeting. This group was in charge 
of examining the stake and problems raised by this project. So far, no progress on these competition matters has been made. However, new WTO agreements on trade in Services (GATS), on intellectual property rights (TRIPS) and on investment (TRIMS) recognize the need of regulation against anticompetitive behaviour, but without going beyond simple recommendation. For instance, services sector, especially telecommunication services, could be subject to the dominance of large firms and to a low degree of contestability. The GATS therefore includes some provisions to preserve competition and promote a neutral regulation of foreign monopoly. State members have to ensure that a monopoly supplier will not abuse his dominant position when competing in the supply of services outside of activities of authorized monopoly. Similarly, intellectual property rights confer a legal monopoly position. In all theses cases, trade could be affected by anti-competitive conducts. Hence the question of trade should be addressed in the context of imperfectly competitive markets.

While the EU has promoted the WTO and the enforcement of binding laws, the U.S. supports a less institutional multinational framework via the "International Competition Network" (ICN), a multilateral cooperation forum. The ICN was initially known as the Global Competition Initiative. The idea of such a forum comes from the International Competition Advisory Committee (ICPAC) formed in 1997 by the U.S. authorities. At this time, U.S. authorities started to worry about the increasing number of cross-border merger reviews and the relative ineffectiveness of its competition instruments abroad, in terms of scrutiny and for instance enforcement. In September 2000, both the U.S. and EU authorities officially expressed their support for the creation of the ICN. The ICN is born in 2001.

The ICN consists in an informal network of antitrust agencies from OECD and non-OECD countries. (See for instance, Hoekman and Saggi, 2005, Bode and Budzinski, 2005, or Todino, 2003.) The ICN is not an inter-governmental body. It was first led by the U.S. and the EU, but was quickly joined by more than 80 other jurisdictions from all around the world. Other institutional members like the WTO, the OECD, and UNCTAD, as well as private actors, participate to this network too. ${ }^{30}$ The ICN aims at improving cooperation on a voluntary basis and thereby at reducing conflicts by sharing information through benchmarking and mutual learning. It has the objective to foster the convergence of national merger review regimes by developing best practices guidelines for enforcement. The ICN only initiates projects on competition issues. It favours discussion and consensus among its members, especially via the constitution of working groups. Different working groups exist like the working group on mergers or cartels. The ICN includes the development of the competition advocacy too, in order to influence government decision makers. It should be pointed out that all propositions promoting harmonization and

\footnotetext{
${ }^{30}$ There exist some clear differences between the OECD and the ICN. (See He discussion by Kurdle, 2005.) The ICN only focuses on competition issues and are opened to all countries, contrary to the OECD. The ICN has no permanent secretariat. While the OECD makes recommendations, the ICN guides countries to best practices through reports and proposals only. The ICN is more a complement than a substitute to the OECD forum.
} 
the adoption of best practices are, like for instance the OECD recommendations, non-binding and purely voluntary. (See Jenny, 2003; Bode and Budzinski, 2005.) They are therefore often called "soft laws". There is no sanctioning mechanism (as in the WTO) in the ICN (or OECD) framework.

After having described the unilateral, bilateral and multilateral institutional instruments of the EU competition policy, we analyse anti-trust problems emerging from market globalisation. The investigation of the pros and cons of the instruments available to policy makers is mainly grounded on existent empirical and theoretical evidence.

\section{WHICH COMPETITION POLICY IN INTERNATIONAL MARKETS?}

\subsection{Interactions, conflicts and efficiency in competition policy: Theory}

\subsubsection{Cross-border externalities and competition regimes}

Competition authorities choose decisions so as to maximize a general objective function. Basically, this objective function is composed of the merging firms' profit (called insider), the non-merging firms' profit (outsider) and the consumer surplus. The weight attributed to each of these components is likely to differ from one authority to another. We return on this point later. The interdependence of antitrust regulations can take two different but related forms, called negative spill-over and distortion effects. (See Falvey and Lloyd, 1999.) Negative spill-overs can be defined as the situation where the action from one country lowers the welfare of another country. There are distortions when this intervention reduces the worldwide welfare too. The non-internalization of externalities could drive authorities to impose a too strict or too lax competition regime as regard the global welfare criterion. Economic literature therefore usually distinguishes type I errors from type II errors possibly done by competition authorities. Type I errors correspond to the case when a practice (for instance a merger) is wrongly blocked by national regulators, while it would induce an increase in the worldwide welfare. Type II errors occur when a conduct reducing the worldwide welfare is nevertheless approved by national regulators. ${ }^{31}$ Fundamentally, these distortions at an international level come from an unequal geographic distribution of gains and losses across countries.

\footnotetext{
${ }^{31}$ As remarked by an attentive reader, the mechanisms that we describe are not really errors, but rather conscious decisions to only address domestic welfare and not to take into account externalities.
} 
At present, we first investigate implications for competition policy under the different regimes of territoriality and extra-territoriality when authorities maximize the national welfare criterion (as it is usually assumed by economists in most theoretical models). Then, we wonder why countries cooperate and how it is difficult to achieve it. It is important to point out the quite limited number of theoretical and even more empirical studies on this question. In addition, research papers usually focus on M\&A only.

The territoriality principle refers to a situation where a country applies its domestic laws only to its own domestic companies. The design of a competition policy in a closed economy is usually driven by a classic welfare trade-off between domestic consumer surplus and domestic firms' profits at home. In the context of open markets, the optimal policy is identical for net importing industries (and more generally net importing country) to the situation without trade since the country has no influence on foreign firms exporting goods at home. They are not able to control foreign firms. In net exporting industries (and countries), authorities fully take into the anti-competitive effects from domestic firms on domestic consumers, but not on foreign consumers. As a result, authorities tend to be laxer. (See Guzman, 1998, 2004.) Thus, competition policy is often viewed as being too lax compared to an optimal global policy, irrespectively of the net country and industry trade balance. Export cartel is a perfect example of underregulation and of beggar-thy-neighbour competition policy: Export cartels decrease the foreign welfare while raising that of the home country. (See Evenett et al., 2001h.) An export cartel can simply be defined as a group of exporters allowed to work jointly when selling products. Thanks to this cooperation, these firms are more likely engaged in price fixing behaviour. It could result in a reduction of trade flows and lower consumer welfare abroad. ${ }^{32}$ When consumers hurt by anti-competitive practices are foreigners, the trade-off of competition authorities is reduced to the maximisation of domestic firms' profits. Anti-trust intervention is deemed irrelevant since export cartels do not affect domestic consumers.

Note that over the last decade a lot of countries have eliminated explicit anti-trust exemption for export arrangement. (See Levenstein and Suslow, 2004.) The European Commission and most of EU members states have abandoned an explicit regime to adopt an implicit one, while the U.S. or Australia for instance continue to maintain this exemption (with notification). The U.S. adopted the export exemption in 1918 by the Webb-Pomerene Export Trade Act, which was revised in 1982 with the Export Trading Company Act. ${ }^{33}$

\footnotetext{
${ }^{32}$ Export cartels can however enhance efficiency. By cooperating in the marketing and distribution of export products abroad (e.g., through a common sale agency), firms are able to share the fixed costs of exporting. Thus, the effect of export cartels could be positive, even for foreign consumers. Efficiency consideration and the promotion of export abroad were questioned in the past, especially in the US: Export cartel exemption was very often employed by multinational firms in the fifties and sixties, and not by small and middle sized firms. Today, this issue is less clear and should certainly not be overstated. (See Levenstein and Suslow, 2004.)

${ }^{33}$ There exist three different regimes as discussed by Levenstein and Suslow (2004): explicit (with or without notification and authorization), implicit and no statutory exemption (no mention of the geographic market). There is an implicit exemption, when export cartels are not subject to national laws.
} 
Similarly to export cartels, if an industry exports all its production, authorities are encouraged to approve anti-competitive national mergers, since it harms foreign consumers only and is advantageous to domestic firms. The assumption of an under-regulation is supported by some theoretical research in economics. Tay and Willmann (2005) conclude that the competition policy is too lax without coordination between authorities when mergers are regulated under the territoriality principle. In their theoretical model, competition authorities have jurisdiction only on mergers located within its territory. Therefore, they are not able to block purely foreign mergers that negatively impact their home country since these mergers do not fall under its jurisdiction. The territorial regimes are thereby more likely to induce type II errors. This is confirmed by Head and Ries for international M\&A (1997). Some mergers may not be banned even though they reduce global welfare if the countries whose consumers are harmed do not have jurisdiction over the merger. When firms and consumers are not located in the same place, the likelihood of type II errors increases. Results from Barros and Cabral (1994) confirm it. Competition authorities may ban domestic mergers that a global authority would allow if the share of domestic demand exceeds the share of domestic supply (and vice versa.). Jurisdictions with a high (resp. low) share of consumers relative to non-merging firms are more induced to enforce strict (resp. lax) competition rules. ${ }^{34}$ Thus, in net exporting industry, they will authorize an anti-competitive domestic merger affecting foreign consumers, generating type II errors. Symmetrically, it could lead to a type I error in net importing industries. For instance, authorities could not take into account positive efficiency effects on foreign consumers. It could be the case of domestic mergers decreasing the cost of supplying foreign markets and lowering competition at home. The main conclusion from economic research is as follows: an increasing asymmetry in the distribution of consumers and producers or company headquarters across countries drives to welfare inefficiency since authorities do not internalize the cross-border effects on other jurisdictions.

The government can therefore decide to adopt the principle of extraterritoriality to remedy to crossborder effects from anti-competitive behaviour conducted abroad. (See Falvey and Lloyd, 1999.) It applies its national laws to companies located within the territory of another nation. Under a regime of extraterritoriality, competition policy could in the opposite become too tough. (See Guzman, 1998, 2004.) A net importer country has clearly an incentive to tighten its competition policy to condemn alleged anticompetitive practices from foreign companies. It tends to over-regulate to defend its consumers to the detriment of foreign firms. Net exporter countries continue to apply laxer competition rules. Therefore, when laws differ from one country to another one, the relevant international regime could be a package of the strictest elements of national laws, as illustrated by the case of Hartford Fire Insurance Co. v.

\footnotetext{
${ }^{34}$ Barros and Cabral analyze the external effects of mergers, i.e., the impact on consumers and non-merging firms - called outsiders us in Shapiro and Farrell (1990). Effects on merging firms (called insiders) are neglected, assuming that these firms decide to merge only if the operation is profitable.
} 
California involving British companies in 1993. (See Guzman, 2004.) Practices of British reinsurance companies was permitted by British laws, but prohibited by U.S. laws. The U.S. Supreme Court stated that there was no true conflict between British and U.S. laws. British firms could comply with both U.S. and British laws. In this case, U.S. authorities were clearly encouraged to sanction this behaviour, since it harmed U.S. consumers, while benefiting to UK firms only. Thus, under extra-territorial regimes, country could more frequently prohibit efficient, as well as inefficient practices, generating more type I errors but less type II errors.

This is confirmed by some more formal models. Authorities block every merger that would be harmful, irrespective of the merging firms' nationality as in Tay and Willmann (2005). Worldwide welfare reducing mergers will never be allowed. Head and Ries (1997) show that, if all countries affected by an international merger have jurisdiction over it, there will be no merger reducing the global welfare. Interestingly, the repeated interaction between authorities may reduce type I errors. (See Cabral, 2005.) In a dynamic framework, each country could accept an international merger proposal that reduce its welfare, but increase the global welfare. The loss from the negative externality could be lower than the punishment cost when deviating from a cooperative strategy.

To sum up, a global competition without a global regulation could lead to too strict and too lax antitrust rules. However, this conclusion should be mitigated because of the practical difficulty to enforce the extraterritoriality principle. (See Grisay, 2005 for instance.) First, international public laws prevent states from exercising their power of coercition on a foreign territory. Second, the power of the Commission to get information and documents abroad is low. It could be in some cases impossible for the country to detect and/or get evidence of the alleged anti-competitive conduct. In Europe, affiliates established within the EU must comply with the request of information, even if the information is located overseas. When companies are located abroad, the Commission can request information to them, but without using its coercive power. It should be made on a voluntary basis. In addition, some countries like Great Britain, Australia, France or for instance South Africa have enacted blocking legislation, mainly to counter the U.S. application of the extraterritoriality principle. (See Senz and Charlesworth, 2001, or Falvey and Lloyd, 1999.) Some laws prohibit the collection and transfer of evidence to foreign body, the enforcement of foreign judgments or the compliance with orders of foreign authorities. There could also exist 'clawback' statutes. They allow “an entity that is the subject of a foreign judgment executed against its foreign assets, to recover the judgment sum against assets of the foreign judgment creditor that are situated in the local jurisdiction.” (See Senz and Charlesworth, p79, 2001.) In addition, the enforcement of the extraterritoriality principle differs greatly among countries depending on the size of the business activity of foreign firms and their assets in this country. The credibility of sanctions for ill-behaved firms varies from one country to another country. Only government who has a strong power over foreign firms by 
keeping their assets or restricting their activity can regulate domestic and foreign firms similarly, independently of the foreign firms' location. In the EU, the Commission cannot compel companies outside the EU to pay a fine. They can only impose monetary sanctions on European affiliates of non-EU companies. The Commission can only use the power of commandment, and not that of coercition to terminate prohibited practices. Finally, authorities have to keep in mind the legitimate interest of other States to avoid conflicts of competence as noticed by Grisay (2005).

The enforcement of extraterritoriality could create serious political tensions and amplify conflicts, as shown in the Boeing-Mc Donnell Douglas case. It could trigger retaliation. The extraterritorially principle then represents one useful, but limited mechanism to solve the issue of cross-border effects of anticompetitive conduct. On the contrary, cooperation through bilateral or multilateral agreement could constitute a mechanism to internalize negative externalities from competition policy decisions. It could permit to achieve a higher global welfare to the benefit of all countries. More broadly, it facilitates a mutual understanding and discussion. However, negotiating a deal will be feasible only with a monetary or non-monetary compensation system, since some countries may lose from an agreement. When going from an extraterritoriality (resp. territoriality) to a cooperation regime, net importing (resp. exporting) countries are likely to lose from a laxer (stricter) optimal regime. Asymmetry in the enforcement of extraterritoriality will increase claims for compensation from powerful countries as predicted by Tay and Willmann (2005). ${ }^{35}$ In addition, payment transfers can incur some transaction costs as noticed by Guzman (1998). These costs notably stem from agency problems and political pressures exerted by industrial lobbyers or voters' population. Besides, imperfect information makes the evaluation of gains and losses from an agreement difficult. There could also be well-known free-riding behaviour: Some winners from the agreement could prefer not to compensate the losers. These costs are probably weaker when the number of countries involved is low and their characteristics are similar.

In practice, current cooperation has experienced some major drawbacks. Exchange of information is very often limited by confidentiality rules. (See Montini, 1999.) The U.S. has signed with the Canada the International Antitrust Enforcement Assistance Act in 1994. It waives confidentiality restrictions under some circumstances. ${ }^{36}$ The exchange of information was more limited with Europe because of possible criminal sanctions and the treble damages rules in U.S. civil suits. More generally, it is difficult for competition authorities to support publicly an improvement in exchange which could be done at the detriment of their domestic firms. There is a risk of information leakage to competing rivals or foreign

\footnotetext{
${ }^{35}$ Since developing countries are usually net importer countries, they should be compensated for a loss in developed countries, which is not realistic because of wealth constraints.

${ }^{36}$ Companies have some interest in authorizing the discussion and the exchange of confidential business information, especially for M\&A investigations (as in the WorldCom/MCI case investigated by both the U.S. and the EU authorities). It alleviates some costs from multijurisdictional merger review (conflicting analyses and remedies, time and money spending, etc.). Companies are much more reluctant in waiving these restrictions in cartel prosecutions.
} 
governments. The difficulty to collect necessary evidence and to interview witness abroad can seriously reduce the ability of authorities to prosecute and punish international cartels. (See Schoneveld, 2003.) The executives of firms can organize and elaborate the formation of the cartel (like meeting, information exchange) outside the domestic country. Besides, difficulties from multiple competences and jurisdiction remain. Let us take the example of cartel prosecution. The non-coordinated accumulation of fines could force the target firm to bankrupt, which could have a very negative impact on market structures. The European court thus rejected the principle of "Non Bis In Idem" (one unique sanction). (See Grisay, 2005.) In the opposite, national laws can be ineffective in deterring international cartels as observed by Evenett et al. (2001h). In the context of multi-market effect, fine and deterrence mechanism based on the domestic market only could be irrelevant. The level of fine could reveal to be too low to deter firms from engaging in an international cartel. Leniency programs could also be less efficient, since a firm would risk being condemned in other countries if it reveals some information at home. It could lead to an inefficient outcome, if the anti-trust monitoring process is not made in parallel. The same issue could be extended to structural and behavioural remedies for mergers and more generally to merger scrutiny. Procedural disparities (difference in timing of merger review) can hinder an effective cooperation. Lastly, a nonbinding cooperation on key antitrust cases could reveal to be insufficient and too fragile in some political and economic context, as shown by the Mc Donnell-Douglas/Boeing and GE/Honeywell conflicts.

The set-up of a binding global antitrust framework enforced by one unique centralized authority could appear as a theoretical solution to remove all costs related to multiple anti-trust reviews and to impose some effective discipline to countries. But, the literature on federalism suggests that responsibility should be assigned to the level of government that is capable of internalising economic externalities. It is called the subsidiary principle. Centralisation could be appropriate only when the gains from the internalisation of externalities are large relative to costs raised by a central authority. This institutional solution indeed may create new kinds of economic inefficiency. Centralisation may generate additional bureaucracy costs. (See Fox, 2003.) Moreover, authorities are distant from the markets that they are in charge to monitor, which accentuates any asymmetry in information. Law could be less suited to the local environment. There could also be an accountability concern. Authorities could purse their own goal and favour particular interest. This problem may be reinforced by lower political pressure from less well-informed citizens. There could be a dilution of local voices in the adoption of laws. Concerted action is also more difficult. There is a higher risk of capture at the benefit of the business community. ${ }^{37}$ Finally, the set-up of a unique global authority will de facto imply the absence of any competition among anti-trust authorities and thus the removal of benchmarking practices.

\footnotetext{
${ }^{37}$ However, it is not clear why this risk could be higher with an international rather than a national regulation office. In addition, a powerful interest group from one country could be counter-balanced by a more powerful interest group from another country. (See Guzman, 2004.)
} 


\subsubsection{A source of conflict: Anti-trust objectives and interpretation}

Also, there can be some disagreement between competition authorities not only because of differences in interests, but also in objectives or economic interpretation. Let us take the example of GE-Honeywell in 2001. This merger conflict is interpreted by many commentators as the outcome of a different view of how this conglomerate merger could have affected competitive market structure. (See Bannerman, 2002.) Based on the portfolio effect theory, the EU prohibited the American merger. The European commission assumed that merging partners would have been able to drive competitors out by bundling goods and services, to the detriment of consumers. Competitors would not have been able to match the offer from this newly merging entity. The U.S. authorities have thought differently: Efficient mergers by leading firms benefit to consumers, even if it could have hurt competing rivals on the short run. In addition to a gap in the economic doctrine, some economists discern underlying industrial policy motivations. (See Patterson and Shapiro, 2001.) The Commission would have given too much weigh to European competitors. This argument was also frequently used to explain the conflict in the McDonnell-DouglasBoeing merger in 1997. Note that in all these cases, the EU strongly denies the allegation of preserving competitors at the detriment of consumers.

In this part of the text, we essentially compare the anti-trust regime in Europe and U.S. The U.S. antitrust laws were established at the beginning of the $20^{\text {th }}$ century to safe competition in the interest of consumers. (See Niels and ten Kate, 2004, and Kurlde, 2005.) A major change occurs in the economic doctrine in the seventies and eighties under the influence of the Chicago school, which advocates a less interventionist policy. The main idea is that anti-trust policy has to protect the process of competition, and not competitors. The ultimate goal is consumer welfare, not competition in itself. Indeed, a market structure can be highly competitive, generating lower prices and a higher quality of goods and services, even if the number of incumbent firms is low. Efficiencies benefiting to consumers should be promoted even if they harm competitors. (See Kolasky, 2004.) On the other side, the EU competition is grounded on the 1957 treaty of Rome and, until very recently, as emphasized in the introduction, one of the main objectives of the European competition policy has been market integration and the formation of a unified European market. This objective would explain for instance the condemnation per se of firms practising price discrimination tending to segment European markets. As such it is not necessarily consistent with economic efficiency and consumer welfare. (See Motta, 2004.)

As underlined by Evenett (2005b), competition laws have not only been focused on a single objective, i.e. consumer welfare, over time and across countries. Antitrust laws have more or less explicitly included other targets, like employment level, income redistribution, small business protection, fairness and equity or dispersion of political and economic power. (See also Motta, 2004.) Especially, conflicts are more 
likely when authorities pursue industrial policy goals. According to the World Bank, industrial policy could be defined as "government efforts to alter industrial structure to promote productivity based growth.”38 (See Evenett, 2005b.) In this context, the formation of national champions are often been supported by some countries at the behalf of dynamic efficiency. Domestic firms would need to reach some critical size threshold to be competitive on global markets. The national champion policy is assumed to improve the competitiveness of domestic firms abroad. It is frequently argued that as a consequence, government should relax competition rules to facilitate this restructuring process. Fundamentally, the national champion policy increases disputes between competition authorities because of political interference and nationalistic preference. In a theoretical paper, Neven and Röller (2000) point out that, with market integration, there could be less and less conflicting decisions since regulators tend to delineate the global market as the relevant market. Regulators assess competitive effects within the same global relevant market when choosing to ban or to authorize a merger. ${ }^{39}$ As a result, divergence tends to occur not because regulators do not protect consumers, but because they pursue nationalistic industry interests. Inherently, the national champion policy has indeed a discriminatory nature against foreign firms, which is not really justified by economic argument. ${ }^{40}$ (On the comparison of compared effects between domestic and cross-border M\&A, see e.g. Bertrand and Zitouna, 2006 a, and Bertrand and Zuniga, 2006. On a discussion on the industrial policy led by EU Member States, see Veron 2006.) In addition, competition and industrial policy do not inherently diverge. ${ }^{41}$ They can be complement. Competition policy exerts a positive action on the productivity of domestic firms, by sanctioning non-efficiency practices. Moreover, competition policy could promote not only static, but also dynamic efficiency. It is wrong to assert that competition policy necessarily hinders the development of R\&D activities. First, the relation between industrial concentration and innovation activities are ambiguous. Some studies conclude that there is a positive link between concentration and innovation as in Mansfield (1968) or Geroski (1995), while others found a negative one or a more complex inverted-U relationship. (See Scherer, 1967 and 1980, Aghion et al., 2002.) There is then no real robust evidence that a laxer competition policy entail a higher innovatory activity. Second, as stressed by Evenett (2005c), dynamic efficiency has already begun to be considered by major jurisdictions in their decision.

Even if anti-trust authorities share similar objectives, disputes can also arise because of a different economic interpretation. It is usually said that the U.S. approach trusts more the market forces overall.

\footnotetext{
${ }^{38}$ The concept of industrial policy and of its instruments is not very well defined. (See Evenett, 2005b). For example, some people underline that industrial policy objective is to facilitate the structural transformation of industries. Instruments of industrial policy are not clearly defined too: it could include investment subsidy, tax credit, import protection etc. The European Commission provides its views on the definition and contents of industrial policy in different documents. See http://ec.europa.eu/enterprise/enterprise_policy/industry/com_2005/com_2005_474_en.pdf for instance.

${ }^{39}$ In their theoretical framework and under the assumption of extraterritoriality regime, conflicts emerge when authorities define a too narrow geographic relevant market.

${ }^{40}$ In some sectors, foreign takeovers can be forbidden (e.g., for security reasons) or be reviewed more strictly by competition authorities.

${ }^{41}$ In addition, exemptions from the competition policy can be attributed as (and particularly) in the regulation of State aids.
} 
(See Niels and ten Kate, 2004.) On the other side, it is said Europeans authorities would be more sceptical by market self-regulation mechanisms. It would explain why European commission pays more attention to leading firms' behaviours and dominances practices. In addition, the Commission's decisions in terms of competition policy were criticized on the ground that they lacked to be founded on sound economic analysis. For a long time, the role of economists remained limited in Europe as compared to U.S. The appointment of a Chief Competition Economist was the sign of a new priority given to the economic approach at the Commission. Now, a real convergence of doctrine between the U.S. and the EU, as with the new Merger regulation and Horizontal Merger Guidelines of 2004, is on the agenda since several years. (See Coppi and Walker, 2004, and Walker, 2005.) In the case of the legal economic test for mergers, the EU partially abandoned its standard dominance criterion (relative to the creation or strengthening of a dominant position) to adopt a closer test that the the U.S. one (relative to a substantial lessening of competition). In the past, the Competition Directorate General of the European Commission used a structural analysis based on market share and concentration ratio to test dominance. It is related to the idea that a concentrated market should reflect a high market power and a weak competition. However, a merger in a differentiated product industry could lead to significantly higher prices over a localized range of products, even if the merging firms are not the largest leading firms in the market. This merger could be prosecuted with some difficulty using the dominance standard. The new European merger guidelines in 2004 call for an assessment of the changes in prices due to the merger, the so-called unilateral effects. (See Walker, 2005) The convergence of approaches between the U.S. and the EU has been even greater in the analysis of coordinated effects from mergers. In the new European Merger guidelines, the risk of tacit collusion occurs only if four necessary conditions are simultaneously met: a common understanding on the terms of coordination (such as price, quality or market division); a monitoring capability of firms; a sanction mechanism when a firm deviates; a lower capacity of nonparticipant firms to undermine the coordination (maverick firms and potential entry). This view is now closer to the U.S. checklist approach. In the past, the European commission did not consider this whole set of conditions as necessary. The EU approach on the efficiency defence has also evolved although the European commission gives less importance to efficiency gains engendered by mergers.

However, there still remain some important practical differences in merger reviews between the U.S. and EU approaches. (See Coppi and Walker, 2004, and Walker, 2005.) For instance, there is little sign of convergence on market delineation issues and market definition. Contrary to the EU, the U.S. gives a reduced role to the concept of market definition since concentration industry tests are less well-considered to the benefit of merger simulation models. Besides, the U.S. market definition is narrower than in the EU method. The U.S. analysis starts from the product offered by merging firms, while the European approach considers more standard industry segmentation. In addition, the EU takes into consideration the supply- 
side substitutability, which is not necessarily the case by the U.S. authority. In other anti-trust fields, vertical restraints continue to be a controversial area. (See Haucaup et al., 2005.) The European approach treats vertical restraints with more suspicion. Some practices like retail price maintenance could be prohibited per se. In the U.S., vertical practices are evaluated under a rule of reason. ${ }^{42}$ There is a detailed investigation on the price and quantity effect of this practice. Differences still persists in competition laws on cartels too. ${ }^{43}$

Due to these differences, the European commission could be biased towards a stricter competition policy although this fact is questioned by Lévèque (2005). Differences in the design of competition policy, that is, in the procedural and institutional framework, can accentuate it. (See Akbar, 2002.) Ex-ante monitoring is more likely to be rigorous in Europe since ex-post sanctions could be more important in the U.S. compared to EU. So far there is no possibility for private suits and treble damages or for instance penal condemnation in Europe. ${ }^{44}$ The European authorities are therefore more wary about potential anticompetitive conduct. This could be reinforced by the fact that referring a decision to the European Court of Justice is possible but usually takes a too long time. Decisions reveal to be quite irreversible given the number of current investigations, although the recent decision in the Sony/BMG case shows that the tribunal may also overturn an approval provided by the Commission. Nonetheless, one must confess that we miss a systematic analysis of the effectiveness of competition policy in the U.S. and the EU. One can just expect that these differences are going to shrink with the on-going reform of European competition laws. Meanwhile, the development of the new economy, partly stimulated by globalization and the access of firms to larger market outlets, gives rise to new challenges. Network industries experience a natural trend to industrial concentration because they require high $R \& D$ expenditures in infrastructure network. Usual competition tools to evaluate dominance and horizontal mergers have to be adjusted for the specificity of these industries. ${ }^{45}$ However, so far, there has been no clear consensus among economists on the right regulation in these new high-technology sectors. As a result, cross-border disputes are likely to increase. (See Röller and Wey, 2002, and Evenett et al., 2000g.) The new economy very certainly represents a new source of divergence in anti-trust issues on the next future, as already suggested by the difference of behaviour of European and American authorities on the very recent Microsoft case. In

\footnotetext{
${ }^{42}$ It can be illustrated by the Virgin/British Airways case in 2001. According to Niels and ten Kate (2004), the U.S. did not declare British Airways guilty for restraint of trade and attempted monopolization. Virgin would have failed to prove any anti-competitive effects on price, output and product quality. Also, it did not show the existence of predatory behaviour. In the opposite, the European commission concluded to an abuse of dominant position. The EU would have condemned the incentive scheme per se of British airways on travel agents, without evaluating the effect on competition.

43 There could be some differences in competition laws on cartels among countries in terms of justifications (deterrence; punishment; compensation for damages), sanctions (pecuniary fines, prison for executives, action for damages and disqualification of executive to run the company) and mitigation of sanctions via leniency programmes (immunity from fines and imprisonment) and authorised cartels (exempted export cartels). (See Schoneveld, 2003.)

${ }^{44}$ In different recent speeches, Mrs Kroes advocates the development of mechanisms by which individuals and companies could be compensated for the effects of antitrust damages. These mechanisms would be part of competition policy as devices to fight anticompetitive practices.

${ }^{45}$ Consumers indeed can benefit from a concentration in an industry where network externalities and complementarities play an important role. However they can be harmed by the presence of switching costs and lock-in effects.
} 
addition, benefits from cooperation (e.g., on standard setting, product compatibility, and licensing) risk amplifying conflicts due to industrial policy issues.

\subsection{Trade and competition policy}

\subsubsection{The import-discipline hypothesis}

The import-discipline hypothesis states that economic openness raises competition in the home market by increasing the imports of goods. (See Cadot et al., 2000, Evenett et al., 2000g.) This applies a procompetitive effect on market structure. Exposures to international competition prevent domestic companies from adopting anti-competitive behaviours. Therefore, it is expected that, with trade liberalization (i.e., lower tariffs and non-tariff barriers), enforcing a strict domestic anti-trust regulation becomes less crucial. ${ }^{46}$ Trade openness could be a substitute for a costly implementation of a competition policy. This substitution hypothesis relies on the robust observation that imports and price-cost margins of domestic firms are negatively correlated. This inverse relation between foreign competition and domestic market power seems usually corroborated by empirical investigations. ${ }^{47}$ Theoretical models in a static setting also usually confirm that a trade liberalisation and an active competition policy could have similar effects in terms of welfare. (See Neven and Seabright, 1997.)

This substitution argument would be particularly relevant for small opened and/or developing countries that lack administrative competencies and financial resources. It is certainly less appropriate for the European community, where trade openness could be insufficient to discipline the practices of domestic firms. Moreover, the import discipline is not extendable to non-trade sectors (i.e., services), which represents an essential industry in our modern economies. Of course, in non-traded sectors, Greenfield FDI could serve as a substitute to imports. (See UNCTAD, 1997.) The liberalization of FDI regime (i.e., lower statutory obstacles and foreign ownership restriction) could contribute to the contestability of national markets in services industries. Nevertheless, the disciplining mechanism could be limited, since start-up fixed costs could be too large to induce foreign firms to enter a domestic market only because of a moderate increase in prices, at least on the short run. In addition, companies can attempt to protect from foreign rivals through different private strategies: product differentiation or for instance vertical arrangements between distributors and manufacturers. ${ }^{48}$ In other words, trade regulation by the

\footnotetext{
${ }^{46}$ See for instance for an exhaustive review of the literature Cadot et al. (2000).

${ }^{47}$ See Jacquemin and Sapir (1991), Levinshon (1993), Roberts and Tybout (1997) or e.g. Thomson (2002). For instance, Jacquemin and Sapir measure this effect in Europe. The disciplinary effect of imports seemed to be more important for extra-EC imports than intra-EC imports. Thomson (2002) gets more mixed results in the 1970s in Canada. There is no clear evidence of pro-competitive effects from trade.

${ }^{48}$ Trade liberalization could also induce domestic mergers. (See on this point for instance, Ben-Ishai, 2005.)
} 
State could be replaced by private barriers to entry. In this case, trade and competition policy should be viewed as complement rather than substitute.

Vertical arrangement as a strategic private tool to restrict foreign market access is well-known since the Kodak case and the related conflict between U.S. and Japanese competition authorities. ${ }^{49}$ Vertical restraints can take different forms, such as exclusive distributors (distributors cannot sell foreign products), exclusive territory (distributors cannot sell outside a specific geographic area) or different discount designs encouraging distributors of not selling foreign products. (See Levinshon, 1996, and Nagoaka, 1998.) Exclusive dealing, vertical integration and refusal to deal may be used to increase the cost of rivals' entry and then to reduce competition on the product markets (inter-brand competition). A restricted access to distribution networks or for instance the impossibility to set up supplier-producer linkages (to get local credit for instance) could block the entry of foreign companies. Territorial constraints (via the prohibition of parallel import) could be used to discriminate prices among countries (intra-brand competition). In this context, a lax competition policy towards the practices of vertical agreement could harm international trade.

Two main points directly stand out from the debate around the import-discipline hypothesis: First, trade affects domestic competition, and reciprocally. Trade liberalization has some implications for antitrust authorities since it affects competition: Trade and FDI competition could be a new source of competition. Actions from foreign exporters and investors have to be evaluated by anti-trust authorities when delineating the relevant market in anti-trust issues, as it is already done usually. ${ }^{50}$ Voluntary export restriction as well as trade restrictive measures (product standard, government procurement etc.) can facilitate anti-competitive practices (like collusion) on domestic markets. Second, without any competition rules, trade can be greatly affected by anti-competitive conducts engendered by vertical arrangements, but also for instance M\&A and cartels.

\subsubsection{Conflicts on the objectives}

Trade and competition policy can enter in conflict. For instance, vertical arrangements could be welfare improving and beneficial to consumers. Indeed, incumbent firms can use vertical restraints to improve their efficiency. Price discrimination can also be beneficial to consumers. An anti-trust policy focusing on consumer welfare could accept such practices. Trade policy would refuse them if they impede trade flows and market access.

\footnotetext{
${ }^{49}$ See also for instance the case of Airbus. Airbus has been alleged to engage in vertical arrangements with its European suppliers (via e.g., standards discriminating against foreign suppliers). It would have restrained sales from non-European suppliers.

${ }^{50}$ For instance, the Korean government blocked a merger in a chemical industry because of a too high level of trade barriers, preventing foreign competition. Similarly, the U.S. took into account the U.S. quota policy which limits the capacity of foreign firms to increase their production in the case of an anti-competitive merger.
} 
Protectionism and competition policy can also diverge. Trade policy mainly shelters the producers' interest, while competition policy aims at protecting national consumers. Anti-dumping measures are an interesting example of an opposition between trade and competition policy. ${ }^{51}$ Anti-dumping measures can consist in compelling exporting firms not to sell below an agreed price or to impose anti-dumping duties equal to the dumping margin (Brülhart and Matthews, 2003). ${ }^{52}$ As anti-trust rules, anti-dumping aims at controlling price discrimination strategy in segmented markets. They could be considered as complement if they are directed to foreign firms, while anti-trust rules address domestic behaviours. ${ }^{53}$ (See Wooton and Zanardi, 2002.) Actually, their real objectives reveal to be different since anti-dumping measures shield industrial business and are very often motivated by political considerations.

The EU has frequently resorted to anti-dumping measures. Over the period 1991 to 2001, there is a slight increasing trend in EU anti-dumping actions. The relationship in the EU between competition principle and anti-dumping policies is rather weak as explained by Messerlin and Reed (1995). Bourgeois and Messerlin (1998) show that less than ten percent of anti-dumping cases investigated by the European Commission correspond to a predatory anti-competitive behaviour. ${ }^{54}$ Anti-dumping procedures are playing an increasing role in trade policy as a substitute for tariff and non-tariff barriers to trade. Indeed, the likelihood of success in an investigation is high, notably in Europe. (See Messerlin and Reed, 1995). In addition, the cost of applying for anti-dumping measures is low as compared to alternative strategy (a price war for instance). Anti-dumping measures raise rivals' costs by increasing the production cost of foreign firms or the risk related to the export activity. (See Messerlin, 1995.) It could thus bring a lower domestic competition level. It may notably facilitate the survival of cartels. ${ }^{55}$ Cartels sometimes try to turn to State intervention and antidumping duties to block entry. ${ }^{56}$ (See Levenstein et al., 2004.) For instance, companies producing ferrosilicon from the U.S. (one of them being a subsidiary of a Norwegian firm) wanted to use anti-dumping laws in the U.S. and Europe to block entry.

\footnotetext{
${ }^{51}$ See for instance for a review of the literature, Niels (2000).

52 See Bourgeois and Messerlin (1998) for a more detailed description of the institutional anti-dumping framework in the EU

53 There are some confusion between predatory dumping and normal dumping commonly used in price discrimination. Dumping is not in itself an anti-competitive practice. Dumping is a component of international trade. Because of competition, domestic prices could be lower to the benefit of consumers. Foreign firms have indeed to accept less important margin abroad due to trade costs. Predatory dumping could drive competitors out of the market and thereby reduce competition. It should be kept in mind that price differences could not be due to an asymmetry in productive efficiency only.

${ }^{54}$ See also for instance Deardorff and Stern (2004).

${ }^{55}$ Consistently with WTO rules, the complaint in the EU should be supported by the Community industry, i.e., "by those Community producers whose collective output constitutes more than $50 \%$ of the total production of the like product produced by that portion of the Community industry expressing either support for or opposition to the complaint.” (See Bourgeois and Messerlin, 1998.) This rule favours collusion.

${ }^{56}$ Cartel members may also use tariff barriers or non-tariff barriers (quotas) to sustain collusion over time by preventing entry or punishing deviating firms (use of trade and statistical report and import surveillance). For instance, the citric acid cartel members ask the government for tariffs protection from China. (See Levenstein et al., 2004.)
} 


\subsubsection{Competition law as instrument of trade policy}

With trade liberalization, competition policy becomes more and more important. Influenced by political pressures and lobbying activity, it could be used as a strategic trade policy to promote national, but also industry interest. As well-known, companies are much more organized to alter policy decisions as compared to consumers. The U.S. were often accused, notably by the United Kingdom, of using competition policy as a trade instrument to facilitate foreign market penetration, which goes against the non-discrimination principle of the WTO. Export cartels can also be an illustrative example.

With trade liberalization, countries are not able to use trade policy to improve their domestic welfare. Competition policy could then be used a substitute to achieve the same goals. While competition policy controls the market power of domestic firms, strategic trade policy attempts to shift rents away from foreign countries by using the market power of domestic firms. (See Levinshon, 1996.) Decisions on competition matters could raise the market share of domestic producers and shift rents.

In a theoretical model, Horn and Levinsohn (2001) examines changes in competition policy when it consists in determining the optimal industrial concentration. Trade barriers affects competition policy: with open markets, foreign firms can sell in the home market, and domestic firms can export abroad. Under some conditions, authorities could be incited to enforce a stricter competition policy (i.e., to increase the number of domestic firms) in order to increase market shares in export markets. Thereby, governments' behaviour can invalidate the substitution hypothesis. Richardson (1999) comes to identical conclusions in a similar theoretical framework. ${ }^{57}$ However, these authors emphasize that it is quite difficult to expect any clear and robust relation between trade and competition policy ${ }^{58}$ It is not clear whether trade liberalization encourages beggar-thy-neighbour competition policy and if a beggar-thyneighbour policy induces a stricter or laxer competition policy. For instance, in a different framework, De Stefano and Rysman (2004) come to the inverse conclusion that government could have a bias to a laxer competition policy, here to the formation of a national champion. A less competitive market structure induces the other country to choose less aggressive taxes. ${ }^{59}$

Section 2 has described the current institutional and political situation of the EU regarding competition issues in international markets. Section 3 has dealt with questions coming from market integration and has provided potential answers to the issues raised. The next and last section provides

\footnotetext{
${ }^{57}$ These models are related to horizontal consolidation and practices. They overlook vertical arrangement and the foreclosure of domestic markets. ${ }^{58}$ The presence of foreign consumers gives an incentive to increase the degree of concentration (assuming that they are no foreign firms). Collusion is then good. With the presence of foreign competitors, the relation is now ambiguous because of rent shifting between foreign and domestic competitors. In addition, there is a third effect taken into account by authorities: industrial concentration affects the home country welfare too.

${ }^{59}$ See also for instance Dixit (1984) or more recently Saggi and Yildiz (2006). Dixit analyses how domestic welfare is related to the number of home and foreign firms, as well as export tariffs and import subsidies.
} 
some related guidance for policy makers in the prospect of the current internal and external reform of the European competition policy.

\section{INTERNATIONAL Challenges to THE EUROPEAN COMPETITION POLICY}

\subsection{External reforms of the European policy}

The increasingly deepening of market integration raises new challenges, which calls for both external and internal reforms of the European competition policy. The extraterritorial application of European competition rules is a way to remedy to cross-border effects from anti-competitive behaviour. However, as explained by many commentators, it is certainly not sufficient for regulating the worldwide strategies of multinationals and exporting firms, even for a powerful anti-trust authority. Besides, as explained in the previous section, often viewed as an infringement of national sovereignty, the extraterritorial principle is a source of international political instability and conflict. Policy markers purely guided by national welfare maximization should therefore be very careful to avoid harmful retaliatory measures. Nevertheless, how to improve the application of the extraterritoriality principle should not be overlooked. A higher ability to enforce EU laws abroad will increase the bargaining power of the EU in current negotiations and will allow EU authorities to defend more credibly their position.

Cooperative solutions are however very clearly to be privileged. For instance, cooperation between the U.S. and the EU Community has displayed numerous successful examples over the last decade, especially during merger investigations. ${ }^{60}$ But, actual bilateral or plurilateral agreements do not seem fully satisfactory. They do not look able to prevent beggar-thy-neighbour policy and conflict, when interests of countries are high. Because of differences in anti-trust framework and unequal distributions of gains and losses across countries, sharing information and communicating is not enough. It does not remove the different costs from multiple anti-trust reviews either. Global rules and/or supervisor with enforcement power could do it. Unfortunately, the idea of a worldwide regulation has sounded politically not realistic and feasible yet. Even with a political support, designing an optimal competition policy is particularly tricky, all the more as there can exist contradiction between trade, competition and other policy objectives as also explained before. There has been no clear consensus about it.

\footnotetext{
${ }^{60}$ It is frequently noticed that cooperation was high and efficient in the cases of Gencor/Lonrho, Exxon/Mobile, Worldcom/MCI, MCI WorldCom/Sprint, BT/AT\&T, Air Liquide/BOC, AOL/Time Warner or Oracle/People Soft.
} 
In the future, three main objectives have to be pursued: the harmonization of rules, especially with the emergence of the new economy; a higher cooperation in the confidential information exchange; the creation of international institutions and mechanisms tackling anti-trust cases generating international spill-overs. All these three elements are of course not exclusive. In practice, besides to bilateral and plurilateral agreements, there are usually two main institutional proposals. (See, e.g., Bode and Budzinski, 2005.) The first one consists in complementing the WTO. Some people support this option, since the WTO already disposes of dispute settlement procedures, which could be extendable to anti-trust issues. Besides, in the Doha Declaration (2001), governments agreed to enter negotiations on antitrust issue. The second proposal is to promote a more informal discussion, mainly through the international competition network (ICN).

With harmonization and convergence of anti-trust laws, competition rules become more identical, which should remove conflicts related to anti-trust goals and interpretations. (See Gerber, 1999, Kudrle, 2005.) As underlined before, efforts on harmonization should not be weakened because of the risks of anti-trust divergence related to the new economy. Convergence can be achieved by unilateral reforms or (binding or not) cooperation and the adoption of common (minimum or not) standards. That was the case with the spread of leniency programs across countries. Frequent contact, discussion and acknowledge of best practices facilitate it. However, the objective of a perfect convergence could just be an illusion, and even more dangerous. (See Shenefield, 2004.) ${ }^{61}$ This process is not irreversible, even without adjustments in substantive rules. It could vary with the composition of anti-trust authorities and courts, and their interpretation of anti-trust provisions. Government authorities have some discretion in the enforcement and interpretation of laws that they can use to its benefit. ${ }^{62}$ More importantly, one-size-fits-all competition law could reveal to be harmful. Law has to be adapted to local political, cultural and historical environment to be really effective. (See Jenny, 2003.) In addition, anti-trust analysis and theory on market structure and firms' behaviour changes over time. Especially in new technological, best practices could evolve rather quickly, requiring frequent adaptations. Cooperation basically means communication, consultation, and information sharing too. (See Kudrle, 2005.) The effectiveness of anti-trust enforcement to foreign conduct is closely dependent on transfers of information. For instance, information sharing is particularly crucial in large-scale cartel investigations. Unfortunately, confidentiality on business activity has been a hard impediment to a real cooperation yet. ${ }^{63}$ To facilitate the exchange of information, agencies need to get waivers from private parties. Companies can profit from information sharing if it reduces the

\footnotetext{
${ }^{61}$ For instance, according to Jenny (2003), it is not so obvious that the U.S.-EU cooperation has really fostered convergence only because agreements on anti-trust affairs are observed. It could simply be explained by no or symmetric effects across U.S. and EU.

${ }^{62}$ In the Kodak case, the U.S. authorities reproached the Japan not to apply existing competition rules on vertical integration for keiretsu.

${ }^{63}$ Authorities are even less free to share and release information in cartel cases because of local laws controlling strictly information during investigations. For instance, in the U.S. or the EU, the identity of amnesty applicants or information provided without the authorization of the applicant cannot be disclosed.
} 
cost of submitting evidence to several authorities and avoids contradictory decisions. But, firms are frequently reluctant to do it due to the risk of information leakage and the misuse of information. ${ }^{64}$ Therefore, a new international legal framework, notably with the U.S., is a high priority to promote the exchange of confidential business information, as recently underlined by Mrs Kroes in 2005. It should be clarified when to permit it and how to develop exchange of legally protected information in safe conditions. ${ }^{65}$ It could replicate the exchange of information in the field of tax and financial securities or criminal activities. The Mutual Assistance Agreements allow highly confidential information exchange but for criminal activity only. The US-Australia agreement is one of the rare agreements facilitating the exchange of confidential information.

In practice, in addition to bilateral and plurilateral agreement, the convergence of substantive laws and the exchange of information could be encouraged by the ICN mechanism. The ICN clearly aims at simplifying cooperation, facilitate voluntary convergence and develop best practice guidelines. (See Haucap et al., 2005.) Another instrument could be more used to overcome informational limits. Based on the positive comity principle, a country can refer a case to the other country's authority. The investigation of the alleged conduct could be easier since the country in charge of the enquiry has an enhanced access to relevant information. The positive comity principle presents other advantages: Competition enforcement could be more effective since domestic authorities have a greater power to terminate this conduct. The positive comity also avoids some duplicated costs and reduces conflicts by giving the only responsibility of the investigation to the country where the anticompetitive behaviour takes place. It substitutes for the application of the territoriality principle. However, the positive comity relies on a high degree of trust. From practical experience, public officials (like R. Pitofsky) have tended to be much less enthusiastic for this tool. It is of no value when laws or/and interests are conflicting, as shown in the main conflicts of Boeing / McDonnell Douglas, GE-Honeywell or Microsoft case. (See Klodt, 2001.) Domestic authorities cannot prosecute domestic firms when they respect national laws, but not foreign laws. Moreover, Comity clauses are non-binding, which is insufficient to prevent real conflict of interest. (See Haucap et al., 2005.) In this context, a further and logical step will be to integrate more binding elements into existing agreements. Nevertheless, it is important to keep in mind that so far, this type of agreement have tended to exclude small less developed countries from cooperation agreement, generating a potential harmful discrimination.

In order to overcome these different aspects, the real cornerstone for reforming international relation is to set up some form of supranational regulation. Theoretically, a global anti-trust supervisor could

\footnotetext{
${ }^{64} \mathrm{EU}$ companies fear for instance private civil prosecution in the U.S..

${ }^{65}$ The prosecution in cartel cases requires more past information on firms' activity than information on future strategic plans as in M\&A control. Information required in cartel case is less confidential. Pre-merger reviews could require materials on sensitive trade secrets or prospective business plans.
} 
permit to internalize economic externalities across frontiers and to achieve a higher global welfare. Unfortunately, countries are not ready to abandon some part of their sovereignty in competition matters. Besides, going to the enforcement of global rules could require a compensation system, which seems very hard to set up. For instance, in M\&A reviews, in addition to the stochastic nature of M\&A, there is no tradition of compensation in anti-trust policy contrary to international trade issue. ${ }^{66}$ (See Tay and Willmann, 2005, Evenett, 2001a.) It is therefore suggested to place negotiation on competition issues in a wider multilateral framework. Countries losing in anti-trust fields could be compensated by favourable measures in other areas, as trade or environment.

In this context, the WTO could appear as the most suited existing instrument. The WTO is a wellknown and experienced international organization. Its competence is highly recognized by the international community. Due to this credibility and legitimacy, the WTO could facilitate the adoption and monitoring of minimum binding competition rules. It reduces the likelihood of diverging and conflicting decisions between countries. (See Bode and Budzinski, 2005.) Furthermore, the WTO already includes a reliable dispute settlement body, which is gaining credibility over time. This institutional mechanism to settle trade dispute has appeared as a credible threat to WTO members. However, this institutional solution does not sound plausible on a near future after the failures of the ministerial conferences of Cancun in 2003, Hong-Kong in 2005 and now in a new meeting in 2006 for the Doha negotiation. Negotiations are indeed very difficult and tedious because of the large number of members and conflicts of interests. Developing countries are in particular very sceptical about competition rules within the WTO. ${ }^{67}$ Besides, it should be noted that the proposal of the EU involving the WTO does not consist in building up a supranational body enforcing international rules and monitoring cross-border cases. Ambition is much more limited. Private firms would not be able to lodge a complaint to the WTO Dispute Settlement body. It would only serve to check that domestic competition laws respect core principles stipulated in the WTO agreement or that national authorities have really done efforts to investigate alleged cases. Therefore, some costs from multiple reviews would not disappear. Perhaps more importantly, the WTO is still dominated by a mercantilist approach and is usually criticised for a lack of expertise in antitrust regulation. ${ }^{68}$ (See Bode and Budzinski, 2005.) Issues on market access within the WTO are mainly focusing on producer interests, and not welfare or efficiency. As emphasised by U.S. officials (like J.

\footnotetext{
${ }^{66}$ For instance, there is no package where a merger reducing the domestic welfare but increasing the global welfare will be accepted by a country in exchange of compensatory measures (over time or not). Each case is evaluated apart from another case.

${ }^{67}$ Some countries argue that they do not to have experience enough to enforce and to negotiate anti-trust issue. (See Mehta, 2003.) They worry that their interest will not be fully considered during this negotiation. (See Bode and Budzinski, 2005.) They see it as an attempt for an even larger access of foreign multinational firms to their markets. Others think that the non-discrimination principle would undermine their industrial policy, notably the national champion policy.

68 As pointed out by another attentive reader, WTO negotiations are more dominated by the mercantilist approach than the settlement of trade disputes.
} 
Klein), by attributing anti-trust responsibilities to the WTO, there is a danger of politicising international antitrust policy even more. (See Hurdle, 2005.)

In the opposite, the ICN has been founded only very recently. Because of its lack of seniority, it is said that the ICN has a lower credibility and reputation compared to the WTO ${ }^{69}$ In addition, it rests on non-binding and voluntary mechanisms. Cooperation mainly depends upon peer pressure and the credibility of involved authorities. From an empirical study on the degree of national conformity with four merger-related Recommended Practices of the ICN, Evenett and Hijzen (2006i) doubt that soft laws will lead in a widespread convergence in national merger regimes because of resource constrains and political pressure faced by many authorities. (See Evenett, 2005d.) Moreover, like the WTO, cost of multiple reviews will not be reduced to zero even if laws converge. But, the ICN has the major advantage to focus on competition matters. Countries are more likely to engage into a dialog process within the ICN because of its informal and soft nature. In this perspective, the ICN could be seen as a useful complement to the WTO. It could constitute a first step before signing more formal and binding agreement. Binding commitments can be more easily negotiated when countries get more experience on anti-trust issues. With experience, the expected size and distribution of the costs and benefits of any reforms appear less uncertain. (See Hoekman and Saggi, 2005.) However, because the ICN mainly promotes best practices between professional anti-trust authorities through propositions, the action of the ICN need to be complemented. The initiatives from the ICN will be usefully articulated with the intervention of the OECD. Indeed, the OECD involves inter-state discussion leading to the adoption of recommendation. The importance of inter-state negotiation should not be understated in the political context of decision-making. Because the OECD gives a less important role to less developed countries, a joint-action with the UNCTAD could be also thought to facilitate dialog and cooperation among developed and less developed countries.

However, if the WTO could serve as an institution to regulate global markets, it will certainly be relevant to distinguish trade and non-trade related competition affairs. The WTO is more qualified and legitimated in judging market access and entry barriers, but less international hard core cartel or M\&A reviews.

As a substitute for the WTO, a multilevel system, like the EU system, could be promoted. This supranational institution could be coupled with an international Court of Justice guarantying the right of defendants. It could be reasonably composed in a first step of a hard core of countries like the EU, Japan and the U.S. With the intensification of economic relation, this solution could appear politically feasible on the long run. Especially, the U.S. authorities could agree to more cooperation as the cost of noncooperating would rise, as they did in the past when they recognize the limits of the extra-territoriality

${ }^{69}$ However the action of ICN is progressively gaining respectability due to its effective role in promoting cooperation. 
principle. The design of a supranational body could be made analogously to the EU model, the relationship between the Commission and the EU member states and the role of the European Court of Justice. It should be decided how to allocate competences between national jurisdictions and a global authority depending on the amplitude of cross-border effects. This unique stop-shop regulation would remove costs from multiple reviews and internalize externalities of competition policy within the area.

This system would be a useful step towards the introduction of a global welfare criterion into antitrust regulation. Of course, the decisions of this anti-trust authority could be detrimental to outside countries, and especially less developed or developing country. Nevertheless, this problem of discrimination could be dissociated. Indeed, more generally, the external dimension of competition policy on developing countries has to be debated, especially to reduce poverty in poor developing countries. To be coherent with the European aid policy towards developing countries, European authorities should take into account their interest when making decisions, although it engenders costs: A direct cost such as enforcement-related resources and an indirect cost such as the reduction in domestic welfare when helping developing countries to sanction and prosecute European domestic companies. Moreover, with the failure of WTO negotiations, current progresses on international anti-trust issues have mainly been performed through bilateral agreements or the inclusion of competition provisions into regional trade agreements. (See Evenett, 2005e.) These forms of cooperation therefore already imply discrimination.

\subsection{Internal reforms of the European policy}

As seen before, the achievement of European competition objectives depends on external instruments. Conversely, internal policies affect the economic relationship of the EU with other partners and its external influence (EU). Internal and external policy have thus to be coherent. ${ }^{70}$ The EU intra-relationship between the Commission and European member states must also be articulated with the external dimension. With the decentralisation of the European competition policy to national agencies, interpretation of substantive laws could differ within the European Union. It could be a new source of divergence within the European Union and between the EU and U.S. authorities. ${ }^{71}$ In addition, there are necessary reforms to undertake to make the European international policy more complementary and to reconcile different objectives. As previously shown, competition and trade policy could reveal to be

\footnotetext{
${ }^{70}$ For instance, the leniency program should be revised to allow firms to get immunized in several markets simultaneously based on damages from all markets. (See Schoneveld, 2003.) Transparency of European decisions facilitates the convergence of rules at an international level since it allows authorities to a better understanding of similarities and differences in anti-trust procedures.

${ }^{71}$ For example, the relationship between the leniency programs of the Community and national agencies has to be clarified. (See OECD, 2005.) There is no single shop where companies can address. Some member states are not endowed with a leniency program or programs differ from one country to another.
} 
contradictory. In the past, trade relationship and the Common trade policy were virtually the only instruments of foreign EU policy. (See Brülhart and Matthews, 2003.)

To contribute to these different points, one first important internal reform could consist in giving a greater awareness and a higher importance of competition issues in the decisions taken by other EU bodies and national regulators, through the instrument of competition advocacy. Because other government policies may affect the European market structure, because different policies are not under the competition authority supervision, notably trade and FDI policy (with the exception for cross-border M\&A) and because some firms or sectors could benefit from exemptions to anti-trust legislation, competition authorities should go beyond enforcing the competition law to ensure competition in these circumstances. Competition authorities have to develop further competition advocacy. Competition advocacy refers "to those activities conducted by the competition authority related to the promotion of a competitive environment for economic activities by means of non-enforcement mechanisms, mainly through its relationships with other governmental entities and by increasing public awareness to the benefits of competition.” (See ICN, 2002.) Recently, it has been extensively discussed in international forums (at OECD, WTO or ICN). It mainly consists in doing reports and performing reviews of existing and proposed laws and regulations, providing advice on potential anti-competitive state measures, educating the public and policy makers and making them aware of competition issues via seminars, newsletters, the use of media etc. (See ICN, 2004, Evenett, 2006f.) Therefore, when addressed by other state bodies, competition issues should be consistent with competition regulation. Competition authorities are confronted in some cases with sector-specific regulators. The latter could hold some important powers of monitoring and control, like in the finance or telecommunication sectors. ${ }^{72}$ Although mainly justified by technical and specific expertise, these regulators could adopt different objectives than competition authorities do, notably in terms of industrial policy. (See Jenny, 2003.) Also, competition authorities should be entitled to comment on regulations imposed on trade and FDI. The European Union still maintain strong barriers to shelter some sensitive sectors. (See Brülhart and Matthews, 2003.) For instance, trade in the service sector remains to be fully liberalized. Anti-dumping should be better controlled in regard to anti-trust matter too. ${ }^{73}$ Competition should not override all other objectives such as the preservation of jobs, the promotion of exports, or national security. But, trade-off between objectives has to be made clear and transparent. (See Bannerman, 2002) Second, trade or sector-specific regulators could particularly be prone to interest groups. Competition issues due to their redistributive impact could also be under the influence of lobbying activities. Authorities are more likely to be subject to criticism

\footnotetext{
${ }^{72}$ Recently, in 1995, the Competition Directorate General initiated investigations in finance and energy to detect potential private constraint and public regulations.

${ }^{73}$ Anti-trust laws could be included in the anti-dumping procedure. (See Hoekman, 1997.) As proposed, a two-tier approach could be adopted. Alleged anti-dumping practices could first judge using the anti-trust criteria. (See Wootong and Zanardi, 2002.)
} 
when the control of business community becomes stricter and fines more substantial. In any case, the role of competition advocacy could be important to counter and neutralize anti-competitive measures initiated by the business community. It could discourage lobbying, which will decrease resources wasting and the risk of regulatory capture.

Of course, competition advocacy is not the panacea. It especially needs to be well-designed if it has to play an important and effective role. (See ICN, 2004, Evenett, 2006f, Clark, 2004.) The role and scope of competition agency in regard to other state bodies should be clear and codify in law to avoid the ineffectiveness of the competition advocacy. It means that institutional rules have in some way to compel other bodies to dialog and take into account the competition view defended by the DG Competition, which is not the case today. In this context, the role and legitimacy of competition will have to be discussed and debated, especially in regards to other social or political objectives. The competition advocacy policy requires also being highly independent from the political influence and based on important human and financial resources to be legitimate and credible in regard to workers, consumers, or businessmen. (See Clark, 2004.) In addition, it raises many other practical questions: Which state measures should be covered by competition advocacy? Which proportion of resources should be dedicated to enforcement and advocacy? How to rationalize the procedure and screening in the legislative process? ${ }^{74}$ How to quantify the impact of competition advocacy and then improve it? ${ }^{75}$ In spite of all these questions, competition advocacy would certainly reveal to be a real complement to competition policy enforcement. ${ }^{76}$ Competition advocacy by promoting competition would reduce the likelihood of anti-competitive conducts and then decrease economic inefficiency. A full enforcement of competition rules would give more credibility to antitrust authorities and then strengthen competition advocacy. Thus, for few years, the Competition Directorate General (DG Comp) has been giving an increasing importance to screening proposals from other bodies of the commission. (See OECD, 2005.) But, the DG Comp does not own a separate unit for competition advocacy. Each Directorate of the Commission is in charge for the impact analysis of its project, and notably the evaluation of consequences on competition. It would certainly be better to give the entire responsibility to the DG comp because of its higher expertise in competition. Making opinion and comments of the competition agency and the response of other bodies more transparent will increase the cost of political interference to antitrust decisions too.

\footnotetext{
${ }^{74}$ Proposals can be numerous during a legislative session. Competition agency resources are limited and should be focuses on anti-trust issue of importance only. (See Clark, 2004.)

${ }^{75}$ It is difficult to assess the effect on legislators and/or regulators. Institutional effects could be visible or occur only on the very long run.

${ }^{76}$ In parallel to competition advocacy, the OECD is currently supporting the self-assessment of competition issues by non-competition bodies through the development of Assessment toolking. (See OECD, 2006.) Indeed, unsolicited advices from competition authorities could imply a hostile reaction from other bodies. Besides, it could absorb too important competition authority resources. However, let us stress again that this step of self-assessment should be formally codified in law to be effective and should require an active role of competition authorities as a promoter, adviser, and designer of the Assessment toolking.
} 
A parallel and complementary reform could consist in making the European competition agency more independent. Different factors may indeed hinder the effectiveness of competition policy: an insufficient institutional and budgetary independence; an overlapping jurisdiction with other regulators and unclear division of responsibilities; a complex set of relations between the courts and competition authorities; insufficient investigatory or enforcement powers; insufficient human qualified and financial resources. In the past, some decisions from EU competition authorities have been largely criticised. They were judged as lacking transparency and being subject to political pressure from member states. (See Sleuwaegen, 1998.) This seems to be less true today according to OECD (2005) while other econometric studies tend to show that the European regulation is protectionist. (See Aktas et al, 2004.) The channel of political influences can be direct when a higher level of administration give recommendations or instructions, but can also be indirect. Independence can be structural or operational. (See Clark, 2004.) Structural independence means a separate body (i.e. not part of a ministry) directly responsible to the parliament for its budget. Operational independence relates to the capacity of authorities to make comments freely and to participate in government issues. It is related to competition advocacy. Nevertheless, the optimal design of competition agency is a complex issue: There exist a wide range of institutional arrangements which could be convenient with some form of independence depending upon the political and history context. For instance, with a total structural independence, the competition body could in some circumstances be short of an access to information and government decisions. Some experience tends to show that even included in a minister and a government, competition authorities can get some form of independence (OECD, 2003).

In the EU, commissioners are politically connected to governments. There is a persistent risk of political interference. The independence of a European Competition Agency would improve its market credibility and legitimacy on international area. By decreasing the likelihood of industrial interest driven motivation and beggar-thy-neighbour actions, it could lower conflicts generated by the application of the extraterritoriality principle and impose more easily a sound economic approach on anti-trust issues during the negotiation with foreign partners. It could take the form of an independent agency separated from the Commission, based on the model of the European Central Bank. The European Medicines Evaluation Agency is one example of allocation of EU functions to outside agencies. (See Bannerman, 2002.) It would be reinforced by competition advocacy prerogatives. Note that a higher independence should go in hand with the highest transparency of DG Competition actions. Efficient internal sanctioning and controlling mechanism should be implemented to guarantee that internal private interests do not influence decisions. It is also important to say that this discussion on the independence of anti-trust authorities is not directly related to the question of the place of the judge in anti-trust issue. This question will become 
particularly important when going to impose penal sanctions for anti-trust practices. Even in a U.S. alike system, the DG Competition as a public prosecutor should have to take independent choices.

\section{CONCLUSION}

The modification of institutional, economic and technological environment poses new challenges to European competition authorities.

With the advent of globalisation, market structures and economic environment have been deeply transformed. Globalisation has stimulated trade and FDI, generating pro-competitive effects on host countries. However, firms' behaviour, particularly through international M\&A and hard-core cartels, could undermine benefits from globalisation. Together with the evolution towards more economic liberalization, markets have been reshaped by important technological improvements, raising new issues in terms of anti-trust policy. These changes have been progressively accompanied by a newly institutional competition framework. The dramatic increase in the number of competition authorities incurs duplicated costs and a waste of resources for multinational firms and anti-trust authorities.

Since several years, the EU has launched a vast program to modernize the European anti-trust regime, mainly because of the liberalization of new sectors and the enlargement to Central and Eastern Europe countries. The increasingly deepening of market integration calls for new external and internal reforms of the European competition policy.

The extraterritorial application of European competition rules reveals to be a limited way to remedy to cross-border effects from anti-competitive behaviour, although a higher ability to enforce EU laws abroad could increase the bargaining power of the EU in the international arena. The EU has clearly to support cooperative solutions. But, bilateral cooperation and especially the implementation of comity principles could be of no value when laws or interests are to highly conflicting, as shown in the past. Three main paths should be encouraged: the continuous harmonization of rules through the joint action of the ICN and the OECD, especially in the context of new technological industries, a source of divergence of anti-trust opinions; a higher cooperation in the confidential information exchange; the set-up of global anti-trust institutions. To this respect, a multilevel system, like the EU system, could be promoted. For political and pragmatic reasons, it could be composed in a first step of a hard core of countries like the EU, Japan and the U.S. It should then be decided how to allocate competences between national jurisdictions and a global authority depending on the amplitude of cross-border effects. The creation of an 
international Court of Justice for competition should also be discussed. This unique stop-shop regulation will remove costs from multiple reviews and internalize externalities of competition policy within the area. In addition to these external reforms, some internal reforms could be required. It should be given a higher priority to competition issues in other EU policies and national regulation. Competition authorities have to develop further competition advocacy. To support this process, institutional internal reforms should compel other EU bodies to consider the competition view adopted by the DG Competition. A parallel and complementary reform could consist in making the European competition agency independent from State Members' interference. The EU has a great responsibility as a leadership in setting-up competition rules worldwide. It has to serve as an example to other competition authorities. Last, but not least, the new challenges faced by European Authorities call for a new research agenda on the effectiveness of competition policy in international markets. Clearly there is a lack of empirical and theoretical investigations to give some guidance for policy makers in the design of competition policy. In particular, it will be particularly interesting to investigate whether the different fields of competition policy (abuse of dominance, mergers, or, e.g., hard core cartels) are differently affected by globalization and with which implications. 


\section{References}

Akbar, Y. (2002), "Grabbing Victory from the Jaws of Defeat: Can the GE-Honeywell Merger Force International Competition Policy Cooperation?,” World Competition, Vol. 25, No. 4.

Aktas, N., de Bodt E., Levasseur M. and A. Schmitt (2000), "The emerging role of the European Commission in mergers and acquisitions monitoring: The Boeing / McDonnell Douglas case," mimeo.

Aktas, N., E. de Bodt and R. Roll (2004), "European M\&A Regulation is Protectionist," University of California, Los Angeles, mimeo.

Aghion, P., Bloom, N., Blundell R., Griffith R. and P. Howitt, (2002), "Competition and innovation: An inverted U relationship," mimeo.

Arnold, J. and B. Smarzynska (2005), "Gifted kids or pushy parents? Foreign acquisitions and plant performance in Indonesia,” Policy Research Working Paper Series 3597, The World Bank.

Bannerman E., 2002, The future of EU competition policy, mimeo.

Barros, P. and L. Cabral (1994), "Merger policy in open economies," European Economic Review, 38, 1041-1055.

Ben-Ishai G. (2005), "Ducking for cover: mergers in response to trade liberalization,” mimeo.

Bernheim, D. and M. Whinston (1990), "Multimarket contact and collusive behaviour," Rand Journal of Economic, Vol.21, №1.

Bertrand, O. (2005), "On the Effects of Economic Integration on Greenfield Investments and cross-border M\&A location pattern,” Journal of Economic Integration, vol.20, $\mathrm{N}^{\circ} 1$.

Bertrand, O. and H. Zitouna (2006a), "Domestic versus Cross-Border Acquisitions: Which Impact on the Target Firms’ Performance,” Applied Economics, forthcoming.

Bertrand, O. and H. Zitouna (2006b), "Trade Liberalization and Industrial Restructuring: the role of Cross-Border Mergers and Acquisitions,” Journal of Economics and Management Strategy, vol.15, $\mathrm{N}^{\circ} 2$.

Bertrand, O. and P. Zuniga (2006), "R\&D and M\&A: are cross-border M\&A different? An investigation on OECD countries,” International Journal of Industrial Organization, vol.24, №2.

Bertrand, O., Mucchielli J-L and H. Zitouna (2006), "Location Choices of Multinational Firms: The Case of Mergers and Acquisitions," Journal of Economic Integration, forthcoming.

Bevin, N. and M. Echevarria (2005), "Gaps and bridges: transatlantic cooperation," The European Antitrust Review

Bjorvatn, K. (2004), "Economic integration and the profitability of cross-border mergers and acquisitions,” European Economic Review, Vol. 48, No. 6, pp. 1211-26.

Bode, M. and O. Budzinski (2005), "Competing Ways towards International Antitrust: the WTO versus the ICN,” Frank Columbus (ed.), New Developments in Antitrust, New York: Nova .

Bourgeois, J. and P. Messerlin (1998), “The . . an Community’s Experience,” Working Paper Brookings Institution, 1998.

Brülhart, M. and A. Matthews (2003), "External trade policy, in El-Agraa,” Ali M. (ed.) The European Union: Economics \& Policies, 7th edition, Prentice Hall.

Cabral L. (2005), “An equilibrium approach to international merger policy,” International Journal of Industrial Organization, 23, 739- 751.

Cadot, O., Grether J-M and J. de Melo (2000), “Trade and competition policy: Where do we stand?,” Journal of World Trade, 34, 1-20.

Clark, J. (2004), “Competition Advocacy: Challenges for Developing Countries,” mimeo.

Connor, J. (2004), "Global Antitrust Prosecutions of Modern International Cartels," Journal of Industry Competition and Trade, vol. 4, issue 3, pages 239-267. 
Coppi, L. and M. Walker (2004), "Substantial convergence or parallel paths? Similarities and differences in the economic analysis of horizontal mergers in U.S. and EU competition law," Anti-trust bulletin, Spring-Summer.

Crampes, C., Encaoua D. and A. Hollander (2005), "Competition and intellectual Property in the European Union," mimeo.

Davison, L. and D. Johnson (2002), "The EU's Evolving Stance on the International Dimension of Competition Policy: A Critical Commentary,” Intereconomics, September/October.

Deardorff, A. and R. Stern (2004), "A Centennial of Antidumping Legislation and Implementation, Introduction and Overview," Research Seminar in International Economics, The University of Michigan, Discussion Paper No. 538.

De Stefano, M. and M. Rysman (2004), "Competition Policy as Strategic Trade with Differentiated Products," mimeo.

Di Giovanni, J. (2005), "What drives capital flows? The case of cross-border M\&A activity and financial deepening," Journal of International Economics, vol. 65(1), pages 127-149.

Dixit, A. (1984), "International Trade Policy for Oligopolistic Industries,” Economic Journal 94, 1-16.

European Commission (2006 a), “Mergers \& Acquisitions Note,” N³ April.

European Commission (2006 b), "Communication from the commission to the European Council of June 2006 Europe In the World - Some Practical Proposals for Greater Coherence, Effectiveness and Visibility".

Guzman, A. (1998), “Is International Antitrust Possible?,” in: New York University Law Review 73, pp. 1501-1548.

Guzman, A. (2004), "The Case for International Antitrust, in: R. Epstein and M. S. Greve (eds.), The New Antitrust Paradox: Policy Proliferation in the Global Economy," Washington, D.C.: AEI Press, (forthcoming).

Evenett S. (2001a), The Antitrust of nations, Introducing Standards for international Antitrust, Harvard International Review.

Evenett, S. (2003g), "The Cross Border Mergers and Acquisitions Wave of the Late 1990s," in R.E. Baldwin and L.A. Winters (eds), Challenges to Globalization, University of Chicago Press for the National Bureau of Economic Research.

Evenett, S. (2005b), “Would Enforcing Competition Law Compromise Industry Policy Objectives?,” In D. Brooks and S. Evenett, Competition Policy and Development in Asia, Palgrave Macmillan.

Evenett, S. (2005c), "What is the Relationship between Competition Law and Policy and Economic Development?,” In D. Brooks and S. Evenett, Competition Policy and Development in Asia, Palgrave Macmillan.

Evenett, S. (2005d), “Soft law and international economic regulation,” GEP Newsletter, February.

Evenett, S. (2005e), "what can we really learn from the competition provisions of regional trade agreements?,” in L. Cernat, P. Brusick and A. Alvarez, editors, Competition Provisions in Regional Trade Agreements: How to Assure Development Gains. New York \& Geneva: United Nations Conference on Trade and Development.

Evenett, S. (2006f), “Competition Advocacy: Time for Rethink?,” Northwestern Journal of International Law and Business, Volume 26, No. 3.

Evenett, S., Lehmann A. and B. Steil (2000 g), Antitrust Goes Global: What Potential for Transatlantic cooperation?, The Brookings Institution Press.

Evenett, S., Levenstein M. and V. Suslow (2001 h), "International Cartel Enforcement: Lessons from the 1990s," World Economy

Evenett, S. and A. Hijzen (2006 i), "Conformity with international recommendations on merger reviews: an economic perspective on "soft law," Mimeo.

Falvey, R. and P. Lloyd (1999), “An Economic Analysis of Extraterritoriality,” GEP Research Paper 99/3

Farrell, J. and C. Shapiro (1990), "Horizontal mergers: An Equilibrium analysis," American Economic Review, Vol. 80, No.1, pp. 107-126. 
Fox, E. (2003), "Can we solve the antitrust problems of globalisation by extraterritoriality and cooperation?," Sufficiency and legitimacy, Anti-trust bulletin 2003.

Fiebig, A. (2005), "Modernization of European Competition Law as a Form of Convergence," Temple International and comparative law journal, 19, 63-86.

Gerber, D. (1999), "The U.S. - European Conflict Over the Globalization of Antitrust Law: A Legal Experience Perspective,” New England Law Review, 34, 123-14.

Geroski, P. (1994), "Market Structure, Corporate Performance and Innovative Activity," Oxford University Press.

Grisay, D. (2005), "International Competition Policy From Extra-territoriality to Multilaterality,” mimeo

Gugler, K., D. Mueller, B. Yurtoglu and Zulehner (2003), "The Effects of Mergers: An International Comparison”, International Journal of Industrial Organization, 21, pp. 625-653.

Haucap, J., Müller F. and C. Wey (2005), "How to Reduce Conflicts over International Antitrust?,” in S. Voigt, M. Albert \& D. Schmidtchen (Hrsg.), International Conflict Resolution: Conferences on New Political Economy 23, Mohr Siebeck: Tübingen .

Hamner, K. (2002), "The Globalization of Law: International Merger Control and Competition Law in The United States, the European Union, Latin America and China," Journal of Transnational Law and Policy, 11, 2, 385.

Hijzen, A., H. Görg and M. Manchin (2005), “Cross-Border M\&A and the Role of Trade Costs”, GEP Research Paper, 2005/17.

Hoekman, B. and K. Saggi (2005), "International Cooperation on Domestic Policies: Lessons from the WTO Competition Policy Debate,” mimeo.

Hoekman, B. (1997), "Competition policy and the Global trading system,” The World Economy, 20, 4, pp. 383-406.

Horn, H. and J. Levinsohn (2001), "Merger Policy and trade liberalization,” The Economic Journal, 111, 244-76.

Horn, H. and L. Persson (2001), “The Equilibrium Ownership of an International Oligopoly,” Journal of International Economics, Vol. 53, Issue. 2, pp. 307-333.

Head, K., and J. Ries (1997), "International mergers and welfare under decentralised competition policy," Canadian Journal of Economics, 30 (4), 1104- 1123.

ICN (2002), “Advocacy and Competition Policy,” Report of the Advocacy Working Group.

ICN (2004), "Competition advocacy in regulated sectors: examples of success," Report of the Advocacy Working Group.

Jacquemin, A. and A. Sapir (1991), “Competition and Imports in the European Industry,” in Winters A. and A. Venables (ed.), European Integration: Trade and Industry, Cambridge University Press.

Jenny, F. (2003), "International cooperation on competition: myth, reality and perspective," antitrust bulletin, vol. XLVIII, Issue 4.

Kabiraj, T. and M. Chaudhuri (1999), "On the welfare analysis of a cross-border merger,” Journal of International Trade and Economic Development, 8: 195-207.

Klodt, H. (2001), "Conflicts and conflict resolution in international anti-trust: do we need international competition rules," The World Economy, Volume 24, Number 7, pp. 877-888(12).

Kolasky, W. (2004), "what is competition? A comparison of U.S. and European perspectives," Anti-trust bulletin, Spring-Summer.

Kojima, T. (2002), "International Conflicts over the Extraterritorial Application of Competition Law in a Borderless Economy,” mimeo.

Kroes, N. (2005), “The First Hundred Days," speech to International Forum on Competition Law, April.

Kudrle, R (2005), “The Globalization of Competition Policy,” mimeo.

Lévèque, L. (2005), "Le contrôle des concentrations en Europe et aux États-Unis : Lequel est le plus sévère ?, " Concurrences, Revue des droits de la concurrence, no 2, p.20.

Levinshon, J. (1996), “Competition policy and international trade,” in Bhagwati, J. and Hudec, R. E. (eds) Fair Trade and Harmonization Vol. 1, Cambridge Mass: The MIT Press, pp. 329-356. 
Levinsohn, J. (1993), “Testing the imports-as-discipline hypothesis,” Journal of International Economics, $35,1-22$.

Levenstein, M., Suslow V. and L. Oswald (2004), "Contemporary International Cartels and Developing Countries: Economic Effects and Implications for Competition Policy,” mimeo.

Levenstein, M. and V. Suslow (2004), "The changing international status of export cartel exemptions," Ross School of Business Paper No. 897.

Lommerud, E., R. Strums and L. Sørgard (2005), "National versus international mergers in unionised oligopoly," RAND Journal of Economics, forthcoming.

Mansfield, E. (1968), "Industrial research and technological innovation: An econometric analysis," Norton, New York.

Mehta, P. (2003), "Living with Cross-border Competition Challenges in the Absence of Global Competition Rules," mimeo.

Messerlin, P. (1995), "Politiques commerciale et de la concurrence, ” Revue Economique, 46, pp. 717-726

Messerlin, P. and G. Reed (1995), "Antidumping policies in the United States and the European Community,” The Economic Journal, vol. 105, pages 1565-75.

Monti, M. (2003), "Contribution of competition policy to competitiveness of the European economy," Institute of European Affairs, May .

Monti, M. (2004 a), “Commentary: Competition Policy in a Global Economy,” International Finance, 7, 3, pp. 495-504.

Monti, M. (2004 b), “A reformed competition policy: Achievements and challenges for the future,” Center for European Reform.

Montini, M. (1999), “Globalization and International Antitrust Cooperation,” FEEM Working Papers

Motta, M. (2004), “Competition Policy: Theory and Practice,” Cambridge University Press.

Nagoaka, S. (1998), “International trade aspects of competition policy,” NBER 6720.

Neary, P. (2004), "Cross-border mergers as instruments of comparative advantage," University College Dublin, mimeo.

Neven, D and P. Seabright (1997), "Trade Liberalization And The Coordination Of Competition Policy" in L. Waverman, W. Comanor and A. Goto. (Eds.), Competition Policy In The Global Economy: Modalities For Cooperation. Routledge.

Neven, D. and L-H. Roller (2000), “The allocation of jurisdiction in international antitrust,” European Economic Review, 44, 845-855.

Niels, G, (2000), "What is antidumping policy really about?," Journal of economic surveys, 14(4), 467 492.

Niels, G. and A. ten Kate (2004), "Introduction: antitrust in the U.S. and the EU: converging or diverging paths," Anti-trust Bulletin, Anti-trust bulletin, Spring-Summer.

Norbäck, P.-J. and L. Persson (2004), "Privatization and Foreign Competition,” Journal of International Economics, Vol. 62, pp. 409-416.

Norbäck, P-J and L. Persson (2005), "Investment Liberalization - Why a Restrictive Cross-Border Merger Policy can be Counterproductive,” Journal of International Economics, Forthcoming.

Patterson, D. and Shapiro C. (2001), "Trans-Atlantic Divergence in GE/Honeywell: Causes and Lessons," Antitrust Magazine, Fall.

OECD (2003), “Optimal design of a competition agency,” Secretariat Note, CCNM/GF/COMP (2).

OECD (2005), "Competition Law and Policy in the European Union,” OECD report.

OECD (2006), "Executive Brief: Competition Assessment,” Working Party №2 on Competition and Regulation, DAF/COMP/WP2.

Qiou, L. and W. Zhou (2006), “International mergers: Incentives and welfare,” Journal of International Economics, 68 38-58.

Raff. H, Ryan, M. and F. Stähler (2006), “Asset Ownership and Foreign-Market Entry,” Economics working papers 2006, 01, Christian-Albrechts-University of Kiel, Department of Economics.

Richardson, M. (1999), “Trade and Competition Policy: Concordia Discors?” Oxford Economic Papers, 51, 649-664. 
Röller, L-H. and C. Wey (2002), "Merger Control in the New Economy,” 2002, CIC Working Papers, FS IV 02-02.

Roberts, M. and J. Tybout, eds. (1997), “Industrial Evolution in Developing Countries.” Oxford: Oxford University Press.

Saggi, K. and H.M. Yildiz (2006), "On the International Linkage Between Trade and Merger Policies," Review of International Economics, vol. 14(2), pages 212-225, 05.

Scherer, F.M. (1967), "Market structure and the employment of scientists and engineers," American Economic Review, 57, pp. 524-531.

Scherer, F. M. (1980), "Industrial Market Structure and Economic Performance," McNally College Publishing Co.

Schoneveld, F. (2003), “Cartel Sanctions and International Competition Policy: Cross-border Cooperation and Appropriate Forums for Cooperation,” World Competition, 26(3).

Scott, J. (1989), "Purposive diversification as a motive for merger," International Journal of Industrial Organization, 7.

Scott, J. (1991), "Multimarket contact among diversified oligopolists," International Journal of Industrial Organization, 9.

Senz, D. and H. Charlesworth, "Building Blocks: Australia's Response to Foreign Extraterritorial Legislation’ (2001) 2 Melbourne,” Journal of International Law, 69-121

Shenefield, J. (2004), "Coherence or confusion: the future of the global anti-trust conversation,” The Antitrust Bulletin, Spring-Summer.

Sleuwaegen, L. (1998), “Cross-Border Mergers and EC Competition Policy.” World Economy, 21, 8: 1077-1093.

Sugden, W. (2002), “Global Antitrust and the Evolution of an International Standard,” Vanderbilt Journal of Transnational Law, 35, 1008.

Tay, A. and G. Willmannn, "Why (no) global competition policy is a tough choice," The Quarterly Review of Economics and Finance, 45 (2005) 312-324.

Todino, M. (2003), "International Competition Network - The State of Play after Naples,” World Competition, Vol. 26 (2), pp. 283-302.

Thompson, A.J. (2002), "Import Competition and Market Power: Canadian Evidence," North American Journal of Economics and Finance, Volume 13, Number 1, May, 40-55(16).

UNCTAD (1997), "Transnational Corporations, Market Structure and Competition policy," World Investment Report.

UNCTAD (2000), “Cross-border Mergers and Acquisitions and Development,” World Investment Report

Véron, N. (2006), "Farewell National Champions," Bruegel Policy Brief 04.

Walker, M. (2005), "Have the Economic approaches to merger control in the EC and the U.S. converged?” The International Comparative Legal Guide to: Merger Control, Global Legal Group.

Wooton, I. and M. Zanardi (2002), "Trade and Competition Policy: Anti-Dumping versus Anti-Trust," James Hartigan, ed., Handbook of Trade and Law, London: Basil Blackwell, Forthcoming. 